\title{
The stele - a developmental perspective on the diversity and evolution of primary vascular architecture
}

\author{
Alexandru M.F. Tomescu \\ Department of Biological Sciences, Humboldt State University, Arcata, California 95521, USA \\ (+1) 707-826-3229 mihai@humboldt.edu
}

\begin{abstract}
The stele concept is one of the oldest enduring concepts in plant biology. This paper reviews the concept and its foundations, and builds an argument for an updated view of steles and their evolution. The history of studies of stelar organization has generated a widely ranging array of definitions of the stele that determine the way we classify steles and construct scenarios about the evolution of stelar architecture. Because at the level of the organism biological evolution proceeds by, and is reflected in, changes in development, concepts of structure need to be grounded in development in order to be relevant in an evolutionary perspective. For the stele, most of the traditional definitions that incorporate development have viewed it as the totality of tissues that either originate from procambium - currently the prevailing view - or are bordered by a boundary layer (e.g., endodermis). A definition of the stele that would bring consensus between these perspectives recasts the stele as a structural entity of dual nature. Here, I review briefly the history of the stele concept, basic terminology related to stelar organization, and traditional classifications of the steles. I then revisit boundary layers from the perspective of histogenesis as a dynamic mosaic of developmental domains. I use classic and recent anatomical and molecular data to reaffirm and explore the importance of boundary layers for stelar organization. Drawing on data from comparative anatomy, developmental regulation, and the fossil record, I offer a model for a stele concept that integrates both the boundary layer and the procambial perspective, consistent with a dual nature of the stele. The dual stele model posits that stelar architecture is determined in the apical meristem by two major cell fate specification events: a first one that specifies a provascular domain and its boundaries, and a second event that specifies a procambial domain (which will mature into conducting tissues) from cell subpopulations of the provascular domain. If the position and extent of the developmental domains defined by the two events are determined by different concentrations of the same morphogen (most likely auxin), then the distribution of this organizer factor in the shoot apical meristem, as modulated by changes in axis size and the effect of lateral organs, can explain the different stelar configurations documented among tracheophytes. This model provides a set of working hypotheses that incorporate assumptions and generate implications that can be tested empirically. The model also offers criteria for an updated classification of steles that is in line with current understanding of plant development. In this classification, steles fall into two major categories determined by the configuration of boundary layers - boundary protosteles and boundary siphonosteles, each with subtypes defined by the architecture of the vascular tissues. Validation the dual stele model and, more generally, in-depth understanding of the regulation of stelar architecture, will necessitate targeted efforts in two areas: (i) the regulation of procambium, vascular tissue, and boundary layer specification in all extant vascular plants, considering that most of the diversity in stelar architecture is hosted by seed-free plants, which are the least explored in terms of developmental regulation; (ii) the configuration of vascular tissues and, especially, boundary layers, in as many extinct species and lineages as possible.
\end{abstract}

\section{Theoretical premises}

The stele concept was introduced by van Tieghem \& Douliot (1886a, b). The history of the concept and of the classification of stele types, as well as most of the attending terminology, were 
reviewed in detail by Beck et al. (1982) and Schmid (1982). According to Schmid (1982), the practice of characterizing the stele as comprising the primary vascular tissues of axial organs and some associated tissues - pith and interfascicular regions - can be traced to Brebner (1902), Farmer \& Hill (1902), and Schoute (1903). Currently, like in the past, some authors use the term stele to refer exclusively to the vascular system (Esau 1965; Beck et al. 1982). While many of these authors regard the stele as including only primary vascular tissues (i.e., primary xylem and phloem, the 'primary stele' of Bower 1908), others have expanded the concept to include also secondary vascular tissues (Cronk 2009). In paleobotany, stele often refers only to the primary xylem, as phloem is infrequently preserved in plant fossils (Beck et al. 1982).

Here, I give the stele a dual definition, as the totality of primary tissues of axial organs (stems, roots or undifferentiated axes) that are (1) derived from procambium and (2) circumscribed by boundary layers. I exclude secondary tissues from the stele because they are indirect, later-ontogenetic derivatives of the procambium; because they do not develop in all vascular plants; and also because their inclusion does not enrich the stele concept in any of its fundamental developmental or evolutionary implications.

The organization of mature plant tissues is the product of development. The primary tissues of axial organs are patterned in apical meristems. Specifically, the architecture of mature vascular tissues, which are the principal components of the stele, is the result of patterning of the procambium in the apical meristem. Thus, a key to stelar organization resides in the procambial architecture established during apical development. Another important aspect of stelar organization is the boundary that circumscribes the fundamental histogenetic domain from within which procambium will be specified (referred to as the provascular domain below; see Section 6: Stele types and boundary layers). Such boundary layers, also established during apical development, can provide another key to stelar organization. However, though discussed by early workers (e.g., Tansley, 1896), the importance of boundary layers has been subsequently downplayed, so that currently the prevailing views emphasize only the procambial origin of the stele.

Within the framework provided by the view that procambial architecture is the main determinant of stelar organization, the geometry of the procambium in the apical meristem region provides the main criterion for defining stele types. This follows the ideas of Beck et al. (1982), who advocated using the architecture of the procambium (or of the protoxylem) for comparing and classifying stelar patterns. A classification of stele types based on procambial architecture typically includes three main types of stele.

\section{Procambial architecture: three main types of stele among tracheophytes}

At the apices of axial organs, the procambium exhibits one of three main architectural configurations that correspond to three main stele types. A protostele is a stele derived from a solid central strand of procambium (Fig. 1a). The procambium is surrounded by ground meristem that matures into the cortex. Vascular strands (leaf traces) may diverge from the stele to supply leaf bases. A siphonostele develops from a hollow cylinder of procambium (Fig. 1b, 2). Aside from ground meristem that differentiates into the cortex that surrounds the stele, siphonostelic axes also possess a central cylinder of ground meristem that forms the mature pith. Another defining feature of the siphonostele is the leaf gap, a discontinuity in the stele immediately above the point of divergence of the trace(s) to a leaf (Fig. 2); the gap is a parenchymatous area and has limited longitudinal extent as it "closes" distal to the leaf trace divergence (Beck et al. 1982). A eustele is a stele derived from a number of discrete procambial strands (Fig. 1c). In cross sections, the strands taken together describe a moreor-less circular outline that separates an outer cortex and a central pith, both derived from ground meristem. The parenchymatous areas between adjacent vascular strands are termed interfascicular areas (or pith rays, sometimes). The discrete strands of vascular tissue that comprise the stele (referred 
to as cauline bundles) and the leaf traces that diverge from them are referred to as sympodia and can form complex patterns. A segment of a cauline bundle between two successive leaf traces is also referred to as a sympodial segment or reparatory strand (Namboodiri \& Beck 1968). It is important to note here that in eusteles the divergence of a leaf trace does not produce a leaf gap (see also Section 2.3: Eusteles).

\subsection{Protosteles}

Protosteles are divided, based on the cross-sectional geometry of the primary xylem (Fig. 3), into haplosteles, actinosteles, and plectosteles. In haplosteles, the xylem has circular to oval shape in cross section (Fig. 3a), in actinosteles it has a lobed (ribbed) shape (Fig. 3b), and in plectosteles it is irregularly dissected into lobes and bands (Fig. 3c) that may anastomose along their trajectory through the axis. The earliest tracheophytes of the Silurian and Devonian had axes with protostelic vasculature (Stewart \& Rothwell 1993). Among extant plants, protosteles characterize the stems of lycophytes, psilotophytes, and some ferns (e.g., Lygodium). Even among siphonostelic ferns, the early growth stages of some species have protosteles (e.g., Gleichenia). A protostele is also the vascular architecture that characterizes the selaginellalean rhizophore and the roots of all tracheophytes, living and extinct.

\subsection{Siphonosteles}

Siphonosteles of different types characterize the stems of most ferns. Depending on the longitudinal density of leaf gaps, siphonosteles are classified into solenosteles and dictyosteles. Solenosteles exhibit no more than one leaf gap at any given level (i.e., in any cross section), whereas dictyosteles can have two or more leaf gaps at the same level. In extreme cases, where multiple leaf gaps occupy a higher proportion of the stele circumference than the sectors occupied by vascular tissue [meristeles sensu Tansley (1907, 1908); see Beck et al. (1982)], such dictyosteles can look misleadingly similar to a eustele, in individual cross sections; e.g., Diplazium or Blechnum (White \& Weidlich 1995), or the fossil Dickwhitea (Karafit et al. 2006).

Solenosteles and dictyosteles can be polycyclic, that is, consisting of two or more concentric hollow cylinders of vascular tissue (e.g., Marattiaceae, Matoniaceae). In such cases, vascular bundles forming leaf traces can diverge from one or several of the stele cycles (e.g., Matonia). Adjacent vascular cylinders of a polycyclic siphonostele can be connected by connective bundles (e.g., Saccoloma, Pteris; Troop \& Mickel 1968). Furthermore, typical siphonosteles of different kinds, whether polycyclic or not, can be variously combined with vascular segments that run along the central pith area (medullary bundles; e.g., Cyathea, Alsophila, Platycerium) or, in some cases, the latter can be occupied by a central vascular cylinder, like in a protostele (e.g., Thyrsopteris, Matonia). All these varieties have been discussed, illustrated, and classified by many, including Bower (1923), Ogura (1972), and Schmid (1982).

\subsection{Eusteles}

Eusteles characterize the stems of all living seed plants. One topic of confusion in discussions of eustelic organization has been the presence of leaf gaps. Some textbook treatments of stelar architecture have perpetuated the idea that eusteles have leaf gaps, a leftover from the earlier view of the eustele as a subtype of siphonostele (Esau 1977) and from classifications based on nodal architecture. These views were also fueled by the inclusion of secondary tissues in the stele concept (Esau 1965) and by observations of eusteles in which numerous cauline bundles and leaf traces give the appearance of a continuous layer of vascular tissues (a condition termed pseudosiphonostely; Beck et al. 1982). However, careful studies of protoxylem architecture (e.g., Benzing 1967a, b) have demonstrated the eustelic nature of pseudosiphonosteles, and the inclusion of secondary tissues does not enrich the stele concept (for reasons discussed above - Section 1: Theoretical premises). Thus, my view is that eusteles do not have leaf gaps. 
Longitudinal sections through eustelic axes can produce vascular tissue configurations that look misleadingly like leaf gaps (Fig. 4a, b) for two reasons. First, in the typical sequence of tissue differentiation behind the shoot apical meristem, nodal tissues mature earlier than those of the internodes. As a result of this, a procambial strand that is conspicuous in a node can appear to lose its substance basipetally, along its trajectory through the internode, and to reappear in the next node below, the same configuration that one would expect to see if a leaf gap was present. Second, in most seed plants, leaf traces diverge from cauline bundles in a tangential direction (Fig. 4c, bottom three planes of section) before traversing the cortex in a radial direction and upwards (Fig. 4c, top three planes of section). This leads to tangential displacement of the cauline bundle above the divergence, as a result of which the cauline bundle shows a hiatus immediately above (distal to) the node in longitudinal sections (Fig. 4b), similar to that produced by a leaf gap in a siphonostele longitudinal section.

Building on the basic sympodial architecture seen in Carboniferous seed ferns and even in Devonian progymnosperms (e.g., Beck 1970, 1971, 1979), the various trajectories of seed plant evolution and diversification have produced a tremendous diversity of eusteles. The sources of this diversity are (1) the increase in the number of sympodia; (2) variations in the connectivity of sympodia, which ranges from discrete unconnected sympodia, to random interconnections (by minor or accessory bundles), to regular anastomoses between cauline bundles or between leaf traces and cauline bundles (e.g., Beck et al. 1982); (3) leaf traces, although not technically part of the stele, can contribute complexity to the stem vascular system, depending on whether they consist of single or multiple bundles, whether these bundles diverge from single or multiple cauline bundles, and whether the traces are short or long (i.e., traversing more than one internode between their divergence from the cauline bundle and their entry into a leaf base). These compounded layers of complexity and diversity have been encompassed in several classification systems (e.g., Schmid 1982). One such classification that dominated the first half of the $20^{\text {th }}$ century was based on nodal anatomy - the architecture of vascular tissues at nodes. Skepticism about the philosophical and methodological bases of this classification, along with the realization that nodal types are adaptive (thus, similar types may not be morphologically equivalent), led to the conclusion that nodal anatomy, by itself, does not provide a conclusive representation of stelar architecture in the absence of internodal features (Beck et al. 1982).

Given the diversity of eustelic architectures, it is important to remember that they all are variations on the same basic sympodial organization. One such variation is seen in the atactostele of some monocots, in which cauline bundles occurring in high numbers undulate in radial planes along their trajectory through the stem. This, along with the emission of numerous, long leaf traces, produces a highly complex organization wherein a multitude of vascular bundles are scattered throughout the ground tissues of the stem, precluding a distinction between pith and cortex. The eustelic organization of atactosteles has been demonstrated by Beck et al. (1982). Although this may be a slight oversimplification, an atactostele can be visualized as a polycyclic eustele with multiple concentric cycles of sympodia.

\section{A bit of history}

Concepts and classifications of steles initiated based on studies of extant plants in the $19^{\text {th }}$ century, gained added impetus in the second half of the $20^{\text {th }}$ century by the contributions of paleobotanists (e.g., Namboodiri \& Beck 1968, Rothwell 1976; Beck et al. 1982), who brought fossil lineages and their vascular architectures to the forefront of discussions of stelar morphology and evolution. This synthesis opened the way to a broader, more inclusive and temporally-constrained perspective on the diversity of stelar architecture and its evolution. Importantly, from their early origins, discussions of stele classification have been firmly rooted in evolutionary views that fit within the same broad paradigm as the modern evo-devo approaches. 
Early on, Jeffrey (1899) recognized two main stele types, the protostele and the siphonostele, a view shared by many morphologists in the early $20^{\text {th }}$ century (Gwynne-Vaughn 1901; Brebner 1902; Tansley 1907, 1908; Bower 1908). Focusing on the deep, early evolution of the vascular system, these workers were not very concerned with the eustele that they regarded as a highly modified siphonostele which, in turn, had evolved from a protostele. In contrast to this view, Boodle (1901), Scott (1902), and others, regarded the eustele as having evolved from a protostele on a parallel trajectory to that of the siphonostele, more consistent with the tripartite protostele-siphonostele-eustele classification. Nevertheless, the scenario of eustele evolution from protosteles favored by these authors required parenchymatization of central tissues associated with formation and expansion of leaf gaps, thus implying a virtually siphonostelic intermediate stage. This view was only different from Jeffrey's ideas in the mechanism proposed for the evolution of the intermediate stage - central parenchymatization, as opposed to the "cortical invasion" process proposed by Jeffrey (see Beck et al. 1982). An origin of the eustele from protosteles was also considered by Posthumus (1924) and, later, by Namboodiri \& Beck (1968), among others. The mechanism proposed by these authors involves ribbing of a protostele and longitudinal dissection to form sympodia (see Section 7.2: Evolution of the pith - siphonosteles and eusteles).

\section{Histogenesis as a dynamic mosaic of developmental domains}

Development in multicellular organisms leads to an organismal body comprised of populations of terminally differentiated cells of different types. During this process, cell differentiation progresses through successive cell fate decision steps. Considered in ontogenetic time, such stepwise cell fate commitment sequences entail increasingly more distinct identity specification, coordinated within wellcircumscribed populations from within volumes of cells that can be regarded as equipotential fields in terms of prior cell fate. These well-circumscribed cell populations represent domains defined by the specific regulatory modules that determine their cell fate. In this context, a developing multicellular body can be regarded as a mosaic of developmental domains. These domains define cell volumes in which the same (set of) regulatory module(s) are expressed at a given moment in ontogenetic time. In this spatially and temporally dynamic mosaic, developmental domains that succeed each other in ontogenetic time can be (partially) overlapping or entirely disjunct.

In plants, the indeterminacy of meristematic growth requires continued circumscribing and specification of developmental domains within the "flow" of new undifferentiated cells produced by the meristem. Generation of a coherent plant body in this mode of growth requires maintenance of longitudinal continuity, both anatomically and physiologically. Given these developmental constraints, specification and maintenance of boundaries that define distinct developmental domains at any given point in time is important throughout the successive levels of increasingly more advanced differentiation, in increasingly smaller and more specific developmental domains of tissue and cell identities.

\section{The importance of boundary layers}

If procambial architecture is a key determinant of stelar organization and provides a workable criterion for defining stele types, these discussions cannot exclude consideration of the boundary layers that separate the developmental domain from within which the procambium is specified, from the adjacent ground tissues. Early on, this was a prevailing view (e.g., Tansley, 1896). However, subsequent treatments concluded that boundary layers, such as the endodermis, had been given undue emphasis and should not be used as criteria in discussions of stelar concepts, a view taken in the most recent exhaustive analysis of stelar concepts by Beck et al. (1982).

My view is that boundary layers are important in discussions of stelar architecture. This view rests on the crucial roles that boundaries and their regulation play throughout plant development - e.g., 
as demonstrated recently for leaf development (Caggiano et al. 2017). In support of this view, accumulating evidence demonstrates that boundary layers, alongside other regulatory systems (auxin and other hormones, tissue or cell identity specifiers, etc.), play an important role in determining the extent and shaping the organization of the stele. For instance, in roots, miR165/166 produced in the endodermis antagonize HD-ZIP III genes (C3HDZ hereafter) that determine procambial identity (Carlsbecker at al. 2010; Miyashima et al. 2011), limiting their expression domain and, thus, determining the volume occupied by procambium. Additionally, by inducing different C3HDZ dosage in different regions of the stele, miR165/166 also specify protoxylem v. metaxylem fates (Hisanaga et al. 2014).

The layers that mark boundaries between the vascular tissues and ground tissues - the endodermis in roots, the starch sheath in stems, and the bundle sheaths of leaf veins - are continuous throughout the plant body (Fig. 5), despite having distinct physiological functions. Available evidence suggests that they are specified by the same regulatory modules throughout the plant body (reviewed by Tomescu 2008) and this shared developmental regulation indicates that they may be serially homologous. Positionally, they are homologous with the endodermal layer that characterizes all the organs of most seed-free plants. Furthermore, the regulation of C3HDZ genes by miR165/166 is shared among all embryophytes (Floyd \& Bowman 2004). This suggests that the antagonistic interaction between miR165/166 and C3HDZ genes, which contributes to circumscription of the stele, is deeply conserved and may have the same function in determining the extent and organization of the stele across the entire tracheophyte clade. All this evidence strongly suggests that the boundary layer that separates vascular tissues from ground tissues is a key determinant of stelar architecture. Thus, contrary to earlier views, boundary layers should be thoroughly considered in definitions and classifications of the steles.

\section{Stele types and boundary layers}

Primary vascular tissues are the principal components of the stele. They differentiate from procambium, and so do other associated tissues typically included in the stele (e.g., the pericycle). Together, these tissues are circumscribed by layers with specific identity, which separate them from other tissues. These well-defined boundary layers, which extend throughout the plant body, indicate the presence of two fundamentally distinct developmental domains: one referred here as the provascular domain, because subpopulations of cells from within it generate vascular tissues, and an accessory domain, consisting of ground tissues. In many axial plant organs, the provascular domain coincides with the stele, thus, the boundary layer defines the extent of the stele.

Overlaying the boundary layer patterns onto the procambium architectural patterns supports some of the stele types defined based on the latter, but also raises questions about some aspects of the tripartite stele classification and some of the traditionally defined subtypes of the three major stele types. Nevertheless, the dual perspective on stelar organization offered by taking into account both procambial architecture and boundary layers provides an updated framework for evaluating hypotheses on the evolution of vascular architecture and stele types.

\subsection{Protosteles}

In most protosteles, a well-defined endodermis separates the stele from the surrounding ground tissues (Fig. 1a, 3, 7e). Exceptions, wherein an endodermal layer is less well defined, include some species of the Lycopodiales and Isoetes. In the latter, the lack of axial elongation and the resulting density of traces to appendages disrupt the stele-cortex limit to an extent that makes recognition of a continuous boundary layer impossible. In most Selaginella species, the endodermis of stems is modified to form a trabeculate layer that includes large air spaces. Additionally, in several species of Selaginella, the stele is dissected into discrete plate-like meristeles, each surrounded by an endodermal layer. 
A special case is that of protosteles that exhibit a central core of parenchymatous tissue, as seen in certain monocot roots (e.g., Zea) or psilotophyte axes (Tmesipteris, Psilotum). This tissue can be interpreted as a pith, suggesting that the stele is in fact a siphonostele. However, the distinction of such forms from siphonosteles and a case against such an interpretation is supported by several lines of evidence: (1) the presence of a well-defined endodermis around the vascular tissues, separating them from the cortex, and the absence of an equivalent boundary layer circumscribing the central parenchymatous core and separating it from the surrounding vascular tissues; (2) gradual longitudinal histologic transitions along the stems of some plants (e.g., Gleichenia; Bower 1908) from a typical protostele, in which the center is occupied by xylem, to a central area of various sizes occupied by parenchyma; (3) a common developmental origin of the vascular tissues and the central parenchymatous area in a central strand of procambium. Thus, this type of anatomy is best interpreted as a medullated protostele.

\subsection{Siphonosteles}

A significant divide among siphonosteles, from a developmental, structural, and evolutionary standpoint, is that between ectophloic and amphiphloic siphonosteles. In ectophloic siphonosteles, primary phloem is found only in a layer external to the primary xylem, whereas in amphiphloic siphonosteles there are layers of phloem both externally and internally to the xylem. In some cases, this separation based on the relative position of phloem and xylem reflects a deeper divide in terms of the radial patterning of developmental domains. Whereas in amphiphloic siphonosteles endodermal layers separate the tissues of the stele from both the cortex (an endodermis external to the outer phloem layer) and the pith (an endodermis internal to the inner phloem layer), in the ectophloic siphonostele of the Osmundaceae there is only one endodermis - between the vascular tissues and the cortex. Thus, if the endodermis marks the boundary between major developmental domains - that generate the stele and ground tissues (i.e., the provascular and accessory domain, respectively) -, then an amphiphloic siphonostele (Fig. $7 \mathrm{~g}$ ) is a true siphonostele, whereas the ectophloic siphonostele of the Osmundaceae is a medullated protostele (Fig. 7f). This view is supported by two lines of evidence. One is structural there are no gaps in the phloem and endodermis corresponding to the gaps in the xylem, thus, the stele as a whole has no leaf gaps, like protosteles and unlike siphonosteles. The other line of evidence is paleobotanical and consists of a transformational time series of fossil osmundaceous genera that go back to the Permian documenting the progressive replacement of the central metaxylem of a protostele by parenchyma (e.g., Kidston \& Gwynne-Vaughan 1914; Miller 1971; Stewart \& Rothwell 1993).

Other ectophloic siphonosteles seem to be true siphonosteles derived by reduction of the inner phloem layer. If that is the case, we expect to still see a boundary layer that separates the xylem from the pith in these plants. However, the latest comparative studies of the anatomy of ferns with such stelar configurations - primarily Vittariaceae (e.g., Vittaria, Antrophyum) - date back to almost a century ago and, as pointed out by Ogura (1972), the accounts of different authors are not entirely consistent. Whereas some authors report presence of well-defined inner phloem and an inner endodermis, others report reduced or absent inner phloem and endodermis (e.g., Williams 1927). Critical reevaluation of these species is needed to test for the presence of a boundary layer based both on anatomical evidence and on specific molecular markers.

\subsection{Eusteles}

An endodermis marked by Casparian strips is rarely seen in stems with eustelic organization (Esau 1977). Nevertheless, substantial evidence from anatomy, physiology, and development indicates the presence of a boundary layer that separates two major domains in eustelic axes - a central domain that includes vascular tissues (the stele) and an outer accessory domain of ground tissues (cortex) (Fig. $7 \mathrm{j}, \mathrm{I})$ - and that provides positional cues crucial for cell fate specification in the establishment of radial 
patterning. In the young portions of many eustelic stems, the innermost cortex layer forms a starch sheath, which shares regulatory mechanisms for identity specification with the root endodermis (see Section 3: The importance of boundary layers). Furthermore, starch sheath cells give histochemical reactions similar to those demonstrated in the endodermis, and these cells can be induced to develop like a typical endodermis (Van Fleet 1950).

Esau (1977) hypothesized that a boundary surrounding the central region of eustelic stems is specified by chemical interaction between materials derived from vascular tissues and those present in the cortex. Developmentally, the segregation of a ring of residual meristem (as seen in cross sections) close behind the shoot apical meristem, from within which procambial strands are specified that connect the stele to leaf primordia (Esau 1977), also suggests the presence of a continuous boundary that delimits a central developmental domain, which includes the vascular tissues, from surrounding ground tissues. Despite being frequently inconspicuous anatomically, this boundary provides positional cues for radial tissue patterning, namely the specification of distinct identities in the two developmental domains that it separates. This is clearly demonstrated in seemingly homogeneous, parenchymatous interfascicular areas, wherein surgical inversion of radial polarity (i.e. cortical domain at the center, central domain outwards) results in inverted polarity of the interfascicular cambium, which produces secondary phloem inwards and secondary xylem outwards (Siebers 1971).

Together, these observations suggest that although vascular tissues are organized in discrete vascular bundles, in eustelic axes the basic radial patterning of tissues includes only two domains separated by a boundary layer - a central domain, which includes tissues that gives rise to the stele, and an accessory external (cortical) domain - much like in a protostele. This conclusion has implications for discussions of stele evolution and classification.

\subsection{Transferability of boundary layer identity}

In discussing the developmental and structural significance of boundary layers, and their importance for understanding stelar organization, it is important to note that the identity of boundary layers is transferrable and their position labile, as suggested by multiple lines of evidence. Stems of some ferns (e.g., Gleichenia; Bower 1908) transition in their epidogenetic growth phase from a protostele to a bona fide siphonostele. This transition that is associated with an increase in stem diameter involves the specification of a pith area and an inner endodermis. Thus, a simple change in size can lead to a major change in stelar organization within the same axis, by generating a central developmental domain and the corresponding boundary layer that separates it from a reorganized domain with vascular competency. Additionally, in some ferns where the vascular tissues form a hollow cylinder, different species of the same genus (e.g., Vittaria, Antrophyum; Williams 1927; see also Section 6.2: Siphonosteles above) may possess only an external endodermis or both external and internal endodermal layers, or even an intermediate, discontinuous internal endodermis. In such cases the lability of the inner endodermal layer blurs the distinction between siphonosteles sensu stricto and what could be considered medullated protosteles.

A comparable situation may be present in some eusteles, as Van Fleet (1961) reports cases where an inner endodermis (also termed a medullary sheath) exists between the pith and the cauline vascular bundles (e.g., Clintonia, Maianthemum) or can be induced experimentally (Vicia). Finally, different species of the genus Equisetum (whose stelar architecture is discussed below; Section 8.2.4: Additional complexity and unknowns) possess one of three possible endodermal configurations including one with an external endodermis and one with both external and internal endodermal layers. Furthermore, these configurations may change within the same plant at the transition from the underground rhizome to aerial shoots (reviewed by Tomescu 2008). Consistent with all these observations that indicate positional lability and transferability of boundary layer identity, Drapek et al. (2018) demonstrated that it is possible to induce formation of ectopic Casparian strips (interpreted as 
reflecting endodermal identity) in subepidermal layers of Arabidopsis roots, and that the transcription factor SHR and the ligand CIF2 are sufficient for this.

\section{Evolutionary considerations}

\subsection{The plesiomorphic protostele}

It is clear that the plesiomorphic stelar architecture is a protostele. The oldest known tracheophytes have protosteles (Kidston \& Lang 1917, 1920a, b; Edwards 1970, 1981; Banks et al. 1975; Gensel 1976; Edwards et al. 1992; Strullu-Derrien et al. 2014; Matsunaga \& Tomescu 2017). The sharp transition that is obvious in these fossil plants between tissues with very different identities - those of the stele and those of the surrounding cortex - indicates the presence of well-defined boundary conditions, thus, it is likely that a mechanism for boundary layer specification existed in the early protostelic tracheophytes. In fact, the protostele-type radial patterning of tissues pre-dates the tracheophytes, as it is seen in plants that lack tracheids and sieve cells - protracheophytes (Boyce 2008; Cascales-Miñana et al. 2019) and even bryophytes, both in the gametophyte and sporophyte phases (Hébant 1977). In all these plants, the conducting tissues form a central cylinder, irrespective of the identity and degree of specialization of these cells, thus, a protostele sensu lato is the plesiomorphic condition of all axial plant organs. Indirect evidence for this also comes from studies of cell fate determination in the pith of the Arabidopsis eustele (Sanchez et al. 2012). Here, the parenchymatous identity of cells is maintained by the WRKY12 transcription factor, in the absence of which the cells develop secondary walls (Wang et al. 2010), like the tracheary elements of the xylem. These data suggest that the default identity of central tissues is similar to that of xylem, supporting the plesiomorphic nature of the protostele. They also suggest a pathway for the evolution of the pith, by suppression of vascular tissue identity at the center of the stele.

\subsection{Evolution of the pith - siphonosteles and eusteles}

Both siphonosteles and eusteles are characterized by the presence of a pith, thus, the evolution of the pith is central to understanding the evolution of stelar architecture. Specifically, this entails addressing when and by what mechanisms pith evolved. The fossil record provides clues relevant to both of these aspects of pith evolution. In terms of timing, axes with a central core of parenchymatous ground tissue are known in both lycophytes (i.e., lepidodendrid isoetaleans) and euphyllophytes (archaeopteridalean progymnosperms, archaeocalamitacean sphenopsids, cladoxylopsids) by the end of the Devonian. By Mississippian time, the seed plants include members that possess a central core of parenchymatous tissue in their stems, and in the Pennsylvanian this feature is also present in several fern groups (e.g., Marattiales, Filicales) (Stewart \& Rothwell 1993). In terms of mechanism, a central core of ground tissue is thought to have evolved either by parenchymatization of the central region of the axis (also known as medullation) or by fragmentation of the central vascular tissues (also referred to as dissection), in both cases starting from a protostele. These two mechanisms have been discussed in relation to different lineages.

In ferns and lycophytes, evolution of the pith is thought to be the result of medullation. In support of this view, the fossil record of osmundaceous ferns provides a compelling series of species that illustrate progressive parenchymatization of the central region of rhizomes occupied by xylem (Kidston \& Gwynne-Vaughan 1914; Miller 1971; Rothwell 1992; Stewart \& Rothwell 1993). Among living ferns, the stem of a single plant may exhibit a size-dependent transition from a protostele with xylem at the center, produced in thinner juvenile stages, to a siphonostele wherein the center is occupied by pith, as the rhizome reaches its mature thickness (e.g., Gleichenia; Bower 1908). A similar size-dependent transition from a bona fide protostele to a medullated protostele along the stems of single plants has been documented in extinct lepidodendrid lycophytes by Eggert (1961). Progressive medullation (of an 
actinostele) has also been proposed as the driver in the evolution of the pith in sphenopsids (reviewed by Stewart \& Rothwell 1993) (Fig. 7h, i), whereas among cladoxylopsids (see also Section 8.3.3: Radial concentration and eusteles) the pith is thought to have evolved by a combination of fragmentation of an actinostele (also referred to as dissection), as a first step, followed by medullation (Stewart \& Rothwell 1993) (Fig. 7h, k, I). For both these lineages, evolutionary scenarios are based on transformational series illustrated by fossil species and an increase in the size of axes may have been one of the drivers of the evolution of the pith.

In the case of the seed plant eustele, the most widely accepted evolutionary scenario posits that longitudinal dissection (fragmentation) of an actinostele produced a system of discrete cauline bundles separated at the center by ground tissue, whose breadth expanded subsequently by progressive medullation (Namboodiri \& Beck 1968) (Fig. 7h, k, I). Seed plants are thought to have arisen from progymnosperm precursors (Stewart \& Rothwell 1993). However, progymnosperms fall within a few lineages (Beck 1976) - most prominent of which are the aneurophytes and the archaeopterids - and the relationships among these lineages, as well as between them and seed plants, are not fully understood (Toledo et al. 2018).

The archaeopterids are considered eustelic (Rothwell \& Erwin 1987), like the derived (and like all extant) seed plants. However, thin archaeopterid stems possess medullated protosteles (actinosteles) whose parenchymatous core widens out in larger stems, separating discrete xylem strands (Carluccio et al. 1966; Scheckler 1978; Beck 1979). Thus, if archaeopterids are the sister group of seed plants, then eusteles would have originated from protosteles directly by medullation not preceded by longitudinal dissection (Fig. 7h, I, j). However, the oldest seed plants have protosteles (actinosteles; Serbet \& Rothwell 1992), like the aneurophyte progymnosperms. If seed plants are monophyletic, then their stelar organization indicates a sister group relationship with the aneurophytes. In this case, the sequence of protostele dissection and subsequent medullation (Fig. 7h, k, I) proposed by Namboodiri \& Beck (1968) and Beck (1970), and refined by Rothwell \& Erwin (1987) and Rothwell (1992) with respect to protoxylem architecture, best explains the origin of the eustele and its pith.

In all the cases discussed above, the development of a central parenchymatous area of the stele is associated with an increase in axis diameter. This, as well as the evolution of specialized lateral appendages (leaves), are thought to have imposed physiological constraints - underpinned by efficiency of water and photosynthate transfer and by economy in the production of energy-demanding specialized conducting tissues - that drove evolution of siphonosteles and eusteles (reviewed by Decombeix et al. 2019). Below, I propose a model informed by current understanding of developmental regulation and sensitive to axis size variation, to provide a unifying explanation for the nature of the stele and its evolution that is consistent with both the procambial and the boundary layer views of the stele discussed above.

\section{A unifying perspective on stelar architecture: the dual stele model}

The dual stele model (Fig. 6) posits two cell fate specification mechanisms that are deployed sequentially and delimit increasingly more narrowly circumscribed and more specialized developmental domains. The first mechanism specifies a provascular domain (not to be confused with provascular tissue, i.e., procambium - e.g. Scarpella et al. 2000), wherein cells maintain the competency to differentiate into procambial tissue, and establishes a boundary layer that separates this domain from the neighboring accessory domain. The second mechanism specifies procambial identity in cells within the provascular domain that will differentiate into xylem and phloem. If the two developmental domain-specifying mechanisms interact and are coordinated, at a higher level of regulation, by an organizer factor acting in a dosage-dependent manner (see Section 8.2: Connections and coordination), together, these conditions could explain the variety of stelar architectures present among tracheophytes. 


\subsection{Potential developmental regulators}

Current understanding of the regulation of radial tissue patterning and vascular tissue development points to potential molecular actors involved in the regulatory mechanisms of the dual stele model. The GRAS family transcription factor SHR could be the master regulator driving the first cell fate specification mechanism that leads to establishment of the provascular domain. SHR has been demonstrated to play an important role in cell division and specification within the stele (Levesque et al. 2006). SHR is produced in tissues that become part of the stele and moves outside of these tissues, activating another member of its gene family $(S C R)$ at their periphery. Together, SHR and SCR establish the boundary layer (Di Laurenzio et al. 1996; Helariutta et al. 2000; Cui et al. 2007). The second mechanism, responsible for procambial identity specification, could be based on HD-ZIP III family genes (C3HDZ), which are emerging as the transcription factors at the center of the regulatory network required for initiating and maintaining vascular tissues (Ramachandran et al. 2017).

In the boundary layer, SHR and SCR activate MIR165/166. In turn, miRNA165/166 move into the provascular domain where they degrade C3HDZ mRNAs, thus circumscribing the expression domain of these genes (Carlsbecker et al. 2010) and, consequently, the procambial developmental domain that will generate the conducting tissues. As a counterbalance to the C3HDZ-miR165/166 interaction, miR165/166 are negatively regulated by $P N H$ (an AGO family gene), which has an expression domain broadly overlapping with C3HDZs and protects them from silencing by miR165/166 (Ramachandran et al. 2017).

Evidence from multiple studies touching on different aspects of these regulatory roles and interactions (e.g., Fukaki et al. 1998; Helariutta et al. 2000; Scarpella et al. 2000; Wysocka-Diller et al. 2000; Floyd \& Bowman 2004, 2007; Juarez et al. 2004; Levesque et al. 2006; Cui et al. 2007; Carlsbecker et al. 2010; Muraro et al. 2014, and many others), reviewed in several papers (e.g., Tomescu 2008; Sanchez et al. 2012; Ramachandran et al. 2017; Campbell \& Turner 2017), shows that they are deployed across all sporophyte organs and wide spread among different plant lineages. Although the picture they paint is still incomplete, when considered collectively these studies strongly suggest that the interactions described above are conserved across vascular plants and may, thus, provide a plausible regulatory framework within which to explore the evolution of stelar architecture.

\subsection{Interactions and coordination}

If the regulatory interactions outlined above are sufficient to determine the extent and geometry of the stele, then they include two aspects that are particularly important for the definition and classification of stele types. First, the two cell fate specification mechanisms that determine the provascular and procambial domains are connected through the intermediary of boundary layers, wherein the provascular domain specifier (SHR) activates a factor (miR165/166) that inhibits the activity of the procambial domain specifier (C3HDZ) (Fig. 6), thus constraining the physical extent of this domain. Second, another unifying aspect is the presence of a putative higher level organizer - auxin. Ample evidence indicates that $\mathrm{C} 3 \mathrm{HDZ}$ gene expression is induced by auxin through the intermediary of auxin response factors, such as MP (Baima et al. 1995; Mattsson et al. 2003; Donner \& Scarpella 2009), and, in turn, C3HDZs promote developmental changes that support auxin canalization (e.g., llegems et al. 2010; Ramachandran et al. 2017). It is unclear what factors act upstream of SHR, but given that (1) the expression domain of SHR consistently includes the procambial domain and (2) polar auxin transport has a key role in shaping this domain, it is likely that SHR has significant interactions with auxin, as suggested by some studies (Levesque et al. 2006; de Luis Balaguer et al. 2017). Thus, it is possible that auxin acts the organizer coordinating the two regulatory mechanisms (Fig. 6). Consistent with this, radial patterning of the Arabidopsis root requires integration of the SHR-miR165/166-C3HDZ interactions network with auxin signaling (Muraro et al. 2014). These connections, some of which are demonstrated 
while others are more putative, indicate that only integration of aspects of both boundary layers and procambial architecture into stelar concepts can lead to deeper understanding of the regulation and evolution of stelar architecture, in the model proposed here.

\subsection{Applying the dual stele model to stele types and reconciling existing data and hypotheses}

\subsubsection{Protosteles and auxin redistribution}

In a protostele, the provascular and procambial domains overlap in the central area of the axis (Fig. 7e), with the exception of a layer that is part of the provascular domain but falls outside the procambial domain and forms the pericycle - bordered by the boundary layer (endodermis). This is consistent with the SHR-miR165/166-C3HDZ interactions demonstrated in roots. Furthermore, the same interactions have also been reported in leaf veins (Wysocka-Diller et al. 2000; Gardiner et al. 2011), which represent cylindrical vascular bundles surrounded by a boundary layer (the bundle sheath) analogous to a protostele. The idea that the procambial domain specifiers - C3HDZs - mediate "central cell fate" (Sanchez et al. 2012), including vascular tissue identity, in the sporophytic axes of early land plants is consistent with the protostelic organization of the earliest tracheophytes (see Section 7.1: The plesiomorphic protostele). Because leaves evolved independently in euphyllophytes and lycophytes (Tomescu 2009), in which C3HDZs are key to development of the protostelic vascular system (Floyd \& Bowman 2006), the role of C3HDZs in regulating vascular programs in the stem predates any roles in leaves (Sanchez et al. 2012).

Development of steles with a parenchymatous central area - medullated protosteles, siphonosteles, and eusteles - could be explained by a common organizer factor that specifies the two developmental domains (provascular and pocambial) in a dosage-dependent manner, activating the provascular domain specifier at lower concentrations and the procambial domain specifier at higher concentrations (Fig. 6). Under these constraints, a limited supply of organizer factor could explain these different stele types as a function of axis size and the influence of lateral appendages on the distribution of organizer concentrations. Auxin is a strong contender for the organizer factor, as discussed above, and auxin homeostasis at the shoot apical meristem may well function based on a limited auxin supply for which multiple sinks compete (Reinhardt 2005).

An increase in the demand of auxin per cross-sectional area of an axis would result in redistribution of auxin concentrations that would, in turn, lead to the reorganization of the developmental domains that determine the patterning of stele tissues (Fig. 7b, c, d). Assuming that the apical meristem area is the main source of auxin, such a disturbance of auxin concentrations could be induced by an increase in axis size unmatched by a corresponding increase in apical meristem size. Irrespective of the underlying cause, redistribution of auxin concentration typical of a protostele in a larger axis under the constraint of limited supply could follow one of two pathways. Peripheral concentration would lead to depletion of auxin in the central region of the axis, to maintain high enough concentrations for procambial specification around the periphery of this area (Fig. 7b, c). Radial concentration would lead to depletion of auxin along radial sectors, leaving a ribbed central area with auxin concentrations high enough for provascular and procambial specification (Fig. 7b, d).

The factor influencing which of the two pathways is deployed by a plant lineage may be the effect of lateral appendages on the distribution of auxin in the apical meristem, in terms of their strengths as sinks or sources. This is consistent with evidence for independent evolution of leaves in ferns and seed plants (Tomescu 2009), whose stelar architectures illustrate peripheral and radial concentration, respectively (see Sections 8.2.2 and 8.2.3 below). In contrast to these euphyllophyte lineages, leaves seem to have little influence on auxin distribution and the structure of the protostele of lycophytes (Floyd \& Bowman 2006, 2010; Gola et al. 2007), consistent with their independent evolution in this lineage. These observations point to the importance of the relationships between lateral 
appendages, with their influence on concentrations of auxin and other putative morphogens in the shoot apical meristem, and stelar architecture. Although not explored in further detail in this chapter, these interactions require further attention.

\subsubsection{Peripheral concentration and siphonosteles}

Peripheral concentration of auxin (Fig. 7b, c) would lead to stelar configurations of the medullated protostele and siphonostele type (Fig. $7 \mathrm{f}, \mathrm{g}$ ). If the central depletion does not take auxin concentration below levels required for activation of the provascular domain specifier, the axis will still possess a central provascular domain bordered by an endodermal layer (Fig. 7f). However, the lower central concentration of auxin will limit specification of the procambial domain (which requires higher auxin concentrations) to the periphery of the provascular domain, as seen in the medullated protosteles of osmundaceous ferns and lepidodendrid lycophytes (in which an endodermis has yet to be demonstrated). The size-dependent medullation in lepidodendrids and the transformational series leading to medullation in fossil Osmundaceae both illustrate this type of stelar transition and demonstrate its developmental feasibility within a plant, as well as in evolutionary time. Severe auxin depletion at the axis center would limit specification of provascular identity to a hollow cylinder of tissue. SHR produced in this reduced provascular domain would then move into adjacent tissues both outwards and inwards, establishing two boundary layers - the outer and inner endodermis characteristic of siphonosteles - and constraining the extent of the procambial domain also between these two layers (Fig. 7g). The size-related transition from protosteles to siphonosteles along Gleichenia rhizomes (Bower 1908) could reflect severe auxin depletion due to peripheral concentration. Cases such as the Vittariaceae (see Section 6.4: Transferability of boundary layer identity) suggest that in some cases development (or evolution) of a siphonostele may go through an intermediate medullated protostele stage (Fig. 7f, g). On the other hand, in siphonostelic ferns experimental suppression of leaf primordia, disturbing the patterns of distribution of auxin produced in the shoot apical meristem (Wardlaw 1946; Soe 1959; Ma \& Steeves 1992), leads to loss of the characteristic leaf gaps and even to protostelic organization, in severe cases (Ma \& Steeves 1992, 1995), consistent with a key role of leaves in determining the distribution of auxin concentrations and, through them, stelar organization.

\subsubsection{Radial concentration and eusteles}

Radial concentration of auxin (Fig. 7b, d) would lead to actinostele-type configurations, wherein the vascular tissues form a central column with longitudinal ridges (ribs) and grooves, wrapped in a boundary layer (Fig. 7h). Records of Early Devonian plants with a ribbed column of central xylem (Gensel 1984; Remy \& Hass 1986; Bickner \& Tomescu 2019) place the origin of actinosteles as far back in time as 400 million years. Higher in the stratigraphic column, actinosteles are present in multiple lineages: cladoxylopsids (iridopterids and some pseudosporochnaleans), stenokolealeans, progymnosperms (aneurophytes and archaeopterids), and early seed plants.

Archaeopterids present a special case indicating that radial concentration and peripheral concentration are not mutually exclusive. Actinoxylon, a Middle Devonian putative archaeopterid (Matten 1968) possesses an actinostele whose central area is occupied by parenchyma with a few scattered tracheids. Even more dramatic is the progressive medullation of the actinostele along archaeopterid stems, as they increase in size distally (Scheckler 1978). These examples suggest that the archaeopterid lineage descended from ancestors in which stelar development followed the radial concentration pathway (Fig. 7d, h). Deployment of the peripheral concentration pathway (Fig. 7h, i, j), in the same way as in medullated protosteles, as a morphogenetic program overprinting the developmental domains generated by radial patterning, subsequently led to a eustelic configuration in archaeopterids. 
The seed plant eustele, the dissected stele of some cladoxylopsids (referred to as a eustele by some; Decombeix et al. 2019), and the stele with discrete vascular bundles present in many sphenopsids, may have arisen along a path similar to that seen in archaeopterids - combining radial concentration and peripheral concentration -, as implied by transformational series and evolutionary scenarios based on fossils (Stewart \& Rothwell 1993). However, in contrast to the archaeopterid pathway, the scenarios proposed for seed plants (Namboodiri \& Beck 1968; Beck 1970) and cladoxylopsids, involve initial fragmentation (dissection) of the actinostele - corresponding to more severe radial concentration - followed by development of a central parenchymatous area due to subsequent peripheral concentration (Fig. 7h, k, I). Furthermore, the medullary sheath reported by Van Fleet (1961) in some angiosperm stems to the inside of the ring of vascular bundles of the eustele, could represent the equivalent of the inner endodermis of siphonosteles, if its boundary layer identity is confirmed. Like in siphonosteles, medullary sheaths would indicate severe auxin depletion at the axis center, as a result of peripheral concentration, that limits specification of provascular identity to a hollow cylinder.

A series of studies have addressed the important role of lateral appendages and their mark on apical meristem auxin concentrations, in shaping the actinostele and the evolutionary trajectory leading to the eustele. Wight (1987) proposed that ribbing of a terete protostele to produce an actinostele was driven by changes in development induced by the effect of lateral appendages on the distribution of auxin concentrations at the axis apex. Rothwell (1992) expanded this evo-devo view to explain the evolution of the seed plant eustele from an actinostele in parallel with the evolution of leaves, and associated changes in protoxylem architecture encompassing the transition from the typical "radiate protoxylem" organization (Beck \& Stein 1993) to the discrete sympodia seen in eustelic seed plants. At the same time, Stein (1993) used modeling to identify a small number of parameters controlling auxin dynamics at the apical meristem and responsiveness of target tissue to auxin concentrations, whose variations produce the types of stelar organization predicted in the scenarios of Beck (1970), Wight (1987), and Rothwell (1992).

Contrary to the eustele evolution scenario proposed for early seed plants, which suggests radial concentration with subordinated peripheral concentration, the development of the angiosperm eustele indicates a different pathway. In Linum, the developmental sequence documented by Esau (1977) in the shoot apex shows a ring-shaped residual meristem from within which procambiun stands are specified subsequently. If the residual meristem corresponds to the provascular domain or its periphery, this developmental sequence suggests that radial concentration - specifying individual procambium bundles - follows (is subordinated to) peripheral concentration that specifies the residual meristem. This reversed sequence (as compared to that proposed for early seed plants ) could reflect the highly derived condition that the angiosperm eustele represents among seed plant steles, which may be the result of heterochronic change in the deployment of radial and peripheral auxin concentration pathways. As the procambium strands that differentiate within the residual meristem are associated with leaf primordia and differentiate into leaf traces, the radial concentration path seems to be controlled by the lateral appendages in the development of the angiosperm eustele.

\subsubsection{Additional complexity and unknowns}

The stelar configurations of some extant and fossil plants continue to be difficult to fit into any stele classification. The steles of the extinct cladoxylopsids, especially non-iridopterid representatives, can be very complex (Bertrand 1935; Leclercq \& Banks 1962; Soria \& Meyer-Berthaud 2003; Xu et al. 2017) and have been likened to plectosteles and eusteles. The scenarios proposed to date to explain their evolution are too simplistic to encompass the broad diversity of structures documented in the group, which is ripe for reassessment in an evolutionary developmental framework. 
Among living plants, Equisetum has puzzled students of plant structure in many respects and its stelar architecture is no exception. In the nodes of its jointed stems, the vascular tissues seem to form a siphonostele, whereas the internodes possess discrete vascular bundles, like those of a eustele (Unger 1856; Barratt 1920; Bierhorst 1971). Additionally, different species possess one of three endodermal configurations, which can also differ between aerial shoots and rhizomes in the same plant (Ogura 1972; Tomescu 2008). The key to understanding the stelar architecture of Equisetum may reside in the particular mode of growth of the shoots of these plants, which arise from the concerted activity of two types of meristems: an apical meristem that lays down a stack of phytomers, and intercalary meristems that fuel the elongation of the internode in each phytomer (Tomescu et al. 2017).

Within this developmental framework, the stele with double endodermis (as an example) of an Equisetum stem could be explained, by the following sequence (Fig. 8): initial specification of a central provascular domain within young phytomers in early stages of radial patterning and subsequent peripheral concentration leading to a hollow cylinder of provascular domain; specification of inner and outer endodermal layers, at the stage of phytomer differentiation into a lower internode tier and an upper nodal tier, in the latter; procambial domain specification in the nodal tier between the two endodermal layers, as leaf primordia emerge, while the internode tier remains meristematic, forming an intercalary meristem; in growing internodes, acroscopic production of new tissue by the intercalary meristem at high rates and fast internode elongation maintain low levels of auxin in the provascular domain (hollow cylinder), precluding specification of procambial domain between the two endodermal layers; procambial strands differentiate within the provascular domain of the internode along vertical lines corresponding to, and under the influence of, leaf primordia. This hypothetical sequence can be tested once the molecular specifiers for the provascular and procambial domains are identified in Equisetum and their expression patterns are documented.

\section{An updated classification of steles outlined}

Applied to stelar classification, the notion that the stele comprises all tissues delimited by the boundary layer(s) results in a dichotomy that recognizes two basic configurations in which the provascular domain either forms a central cylinder or a hollow cylinder. At first glance, this bipartite scheme, which harkens back to the early views of Jeffrey (1899), provides an alternative to the tripartite scheme based on procambial architecture. However, this boundary layer-based view is grounded in development and cell fate specification just as much as the procambial perspective. Neverthless, in the dual stele concept discussed in the preceding sections the former operates at a higher level of generality than the latter. Here, I propose an updated classification that takes into account these considerations, based on the dual stele concept.

To avoid introducing unnecessary additional terms, I refer to the two major types of steles corresponding to the two basic configurations of the provascular domain - and its boundary layer(s) - as boundary protosteles (central cylinder of provascular tissue with only one boundary layer at the periphery) and boundary siphonosteles (hollow cylinder of provascular tissue delimited by inner and outer boundary layers) (Fig. 7).

Boundary siphonosteles correspond, for the most part, to bona fide siphonosteles seen in many living ferns, i.e., amphiphloic siphonosteles wherein the procambial domain overlaps with the provascular domain, except for the inner and outer pericycle layers (Fig. 7g). Stelar architecture in the Equisetum example discussed above (Fig. 8; Section 8.3.4: Additional complexity and unknowns) also corresponds to a boundary siphonostele. In this case, given the discrete vascular bundles that form the vascular supply of internodes, their vascular organization would qualify as a eustelic boundary siphonostele.

Boundary protosteles can fall within a number of subtypes, depending on the organization of the procambium within the provascular domain (Fig. 7). Haplostelic boundary protosteles (Fig. 7e) 
correspond to the typical protostele with a terete procambial strand, as in thin or young Gleichenia stems, or the axes of fossil zosterophylls (e.g., Zosterophyllum) and trimerophytes (e.g., Psilophyton). The steles of all roots are also haplostelic boundary protosteles. Their traditional designation as actinosteles is a misnomer, as only their xylem, and not the procamium as a whole, is lobed (ribbed). A more correct designation for root steles is as haplostelic boundary protosteles with lobed xylem. In the same line of reasoning, the steles of Lycopodium or Selaginella stems, traditionally referred to as actinosteles and plectosteles, are also haplostelic boundary protosteles with lobed or dissected xylem.

True actinostelic boundary protosteles (Fig. $7 \mathrm{~h}$ ) with a ribbed column of procambium are seen in Psilotum and Tmesipteris, as well as in some extinct progymnoperms, stenokolealeans, and cladoxylopsids. Other cladoxylopsids possess putative plectostelic boundary protosteles (i.e. dissected column of procambium), although a single boundary layer surrounding all the vascular segments of an axis would need to be identified unequivocally in these extinct plants for this assignment to be validated.

In siphonostelic boundary protosteles (Fig. 7f), the procambium forms a hollow cylinder. This assignment applies to the stelar organization of the traditional medullated protosteles of monocot roots, and to the ectophloic "siphonostele" of the Osmundaceae and some other ferns (e.g., Vittariaceae pro parte). If the large medullated axes of lepidodendraleans do not possess an internal boundary layer separating the pith from the vascular tissues, then their organization also corresponds to siphonostelic boundary protosteles.

Finally, because they are bordered only by an external boundary layer, seed plant eusteles also qualify as boundary protosteles, designated here as eustelic boundary protosteles, in reference to the discrete strands of protoxylem that differentiate within, and close to the periphery of, the central provascular domain (Fig. 7j, I).

To be fully supported and, thus, become fully applicable, this classification based on developmental features requires that some significant knowledge gaps are filled. On one hand, neither procambial architecture nor boundary layers are easily documented or even preserved in the fossil record, therefore the classification is not readily applicable to many fossils. Apical meristems demonstrating procambial architecture are rarely preserved in the fossil record and, except for endodermal layers with conspicuous thickenings, boundary layers are not easily identified in fossils. Nevertheless, instances of excellent preservation of apical meristems (e.g., Melchior \& Hall 1961; Delevoryas 1964; Good \& Taylor 1972; Dennis 1974; Edwards 1994; Slater et al. 2015; Hetherington et al. 2016; Hetherington \& Dolan 2018) indicate that continued exploration of the fossil record will reveal more about procambial architecture in extinct plants. On the other hand, boundary layer identity seems to be positionally labile (see Section 6.4: Transferability of boundary layer identity), and understanding boundary layer specification across all tracheophyte lineages is still a remote target. Thus, the classification I propose here is, for now, an outline. Nevertheless, a dual outlook on the stele that combines the procambial view and the boundary layer perspective is developmentally grounded and can inspire interesting perspectives on the evolution of stelar architecture that are worth pursuing. This classification, alongside the dual stele model that it is derived from, forms an extended working hypothesis toward this goal.

\section{Outstanding questions and future research}

Because of the paramount importance of conducting tissues in vascular plants, the stele is one of the oldest enduring concepts in plant biology. Although the concept has generated much discussion throughout its history and there is general agreement that the stele includes vascular tissues, current definitions of it vary in specificity and inclusiveness. Among these, those that are grounded in development - the only ones that are relevant in an evolutionary perspective -, emphasize either boundary layers or, more prevalently, the procambium. 
To reconcile these different views, I propose the dual stele model, a stele concept that incorporates both boundary layers and procambium as originators and key components of the stele. This model posits that the stele is determined by specification of provascular and procambial developmental domains (the latter nested within, and regulated through inhibitors produced by, the former) by lower and higher concentrations, respectively, of a coordinating organizer factor. The proposed regulatory framework for the dual stele model is based on current understanding of the molecular-genetic regulation of boundary layer and procambium identity in a few angiosperm species. Thus, the model is a set of working hypotheses. Testing of these hypotheses and refining of the model, if confirmed, will require development of new data in two major directions of investigation.

One of these directions addresses the regulators of procambial, vascular, and boundary layer identity. The full system of interactions between these regulators requires some refining even in angiosperms, wherein it is well outlined currently. Beyond the realm of angiosperms (and, to some extent, seed plants), these regulators and their interactions have spotty data coverage, if any. The presence, expression patterns, functions, and interactions of C3HDZs, SHR, SCR, miR165/166, as well as auxin distribution and transport, have been slow to be explored in seed-free plants over the last 10-15 years, although there are notable exceptions (e.g., Floyd \& Bowman 2004, 2006, 2007; Prigge \& Clark 2006; Sanders \& Langdale 2013; Frank et al. 2015; Ambrose \& Vasco 2016; Vasco et al. 2016). These are all important in understanding what determines stelar organization, considering that seed-free plants harbor most of the diversity of stelar architecture.

The functions of C3HDZ genes in vascular identity and development have been confirmed, in general, in many tracheophytes (Floyd \& Bowman 2006; Floyd et al. 2006; Ambrose \& Vasco 2016). Aside from refining the functional data on C3HDZs and adding more data points (i.e., more species and lineages), it will be interesting to understand if and what aspects of the development and specification of boundary layers, which are ubiquitously associated with vascular tissues and the stele, share regulatory mechanisms across all tracheophytes; if there is a shared specifier of the provascular domain and if that key regulator is also part of the module that specifies boundary layers in all vascular plants. If the same regulatory module specifying the boundary layer is shared among all living tracheophytes, then this module may have evolved as early as or even before the oldest tracheophytes. If such a regulatory mechanism is not shared in its entirety, then are there any components of it that are shared among all tracheophytes? Answers to all these questions will help identify boundary layers in extant plants even in the absence of diagnostic anatomical features and will clarify how much sense it makes to use boundary layers to define and classify steles.

The other major direction of investigation should aim to document in detail the vascular architecture and anatomy of boundary layers in as many extinct species as possible. The fossil record, traditionally decried as incomplete, has offered, nevertheless, surprisingly detailed data on tissue- and cell-level anatomy in multiple cases. Xylem is among the most frequently and best preserved plant tissues in the fossil record and, although phloem and other "softer-walled" tissues (such as those that form boundary layers) or apical meristems are preserved less frequently, continued exploration of the fossil record will uncover new data on boundary layers and stelar architecture in extinct plants.

Although not discussed here, patterns of primary xylem maturation and the architecture of the protoxylem are another aspect of plant anatomy important in understanding vascular tissue differentiation and the organization of steles (Beck et al. 1982). Thus, future studies addressing these aspects could illuminate in detail the relationships between protoxylem, patterns of polar auxin transport, and their respective regulatory programs. Eventually, this type of data could provide answers to basic questions, such as the ultimate causes of the fundamental difference in primary xylem maturation between the exarch-zosterophylls and lycophytes, and the centrarch-mesarch trimerophytes and euphyllophytes; or of the difference in primary xylem maturation between euphyllophytes with 
813 "permanent protoxylem" (sensu Beck \& Stein 1993) (i.e., moniliformopsids; Kenrick \& Crane 1997) and 814 those with "radiate protoxylem" (radiatopsids). 


\section{References}

Ambrose, B.A., Vasco, A., 2016. Bringing the multicellular fern meristem into focus. New Phytologist 210, 790-793.

Baima, S., Nobili, F., Sessa, G., et al., 1995. The expression of the Athb-8 homeobox gene is restricted to provascular cells in Arabidopsis thaliana. Development 121, 4171-4182.

Banks, H. P., Leclercq, S., Hueber, F.M., 1975. Anatomy and morphology of Psilophyton dawsonii, sp. n. from the Late Lower Devonian of Quebec (Gaspé), and Ontario, Canada. Palaeontographica Americana 8, 75-127.

Barratt, K., 1920. A contribution to our knowledge of the vascular system of the genus Equisetum. Annals of Botany 34, 201-235.

Beck, C.B., 197. The appearance of the gymnospermous structure. Biological Reviews 45, 379-400.

Beck, C.B., 1971. On the anatomy and morphology of lateral branch systems of Archaeopteris. American Journal of Botany 58, 758-784.

Beck, C.B., 1976. Current status of the Progymnospermopsida. Review of Palaeobotany and Palynology 21, 5-23.

Beck, C.B., 1979. The primary vascular system of Callixylon. Review of Palaeobotany and Palynology 28, 103-115.

Beck, C.B., Stein, W.E., 1993. Crossia virginiana gen. et sp. nov., a new member of the Stenokoleales from the Middle Devonian of southwestern Virginia. Palaeontographica B 229, 115-134.

Beck, C.B., Schmid, R., Rothwell, G.W., 1982. Stelar morphology and the primary vascular system of seed plants. Botanical Review 48, 691-815, 913-931.

Benzing, D.H., 1967a. Developmental patterns in stem primary xylem of woody Ranales. I. Species with unilacunar nodes. American Journal of Botany 54, 805-813.

Benzing, D.H., 1967b. Developmental patterns in stem primary xylem of woody Ranales. II. Species with trilacunar and multilacunar nodes. American Journal of Botany 54, 813-820.

Bertrand, P., 1935. Contribution à l'étude des cladoxylées de Saalfeld. Palaeontographica B 80, 101-179.

Bickner, M.A., Tomescu, A.M.F., 2019. Structurally complex, yet anatomically plesiomorphic: permineralized plants from the Emsian of Gaspé (Quebec, Canada) expand the diversity of Early Devonian euphyllophytes. IAWA Journal 40, doi: 10.1163/22941932-40190234

Bierhorst, D.W., 1971. Morphology of vascular plants. Macmillan, New York.

Boodle, L.A., 1901. Comparative anatomy of the Hymenophyllaceae, Schizaeaceae, and Gleicheniaceae. II. On the anatomy of the Schizaeaceae. Annals of Botany 15, 359-421.

Bower, F.O., 1908. The origin of a land flora. A theory based upon the facts of alternation. Macmillan, London.

Bower, F.O., 1923. The ferns (Filicales) treated comparatively with a view to their natural classification. Vol. 1, Analytical examination of the criteria of comparison. Cambridge University Press, Cambridge, UK.

Boyce, C.K., 2008. How green was Cooksonia? The importance of size in understanding the early evolution of physiology in the vascular plant lineage. Paleobiology 34, 179-194.

Brebner, G., 1902. On the anatomy of Danaea and other Marattiaceae. Annals of Botany 16, 517-552.

Caggiano, M.P., Yu, X., Bhatia, N., et al., 2017. Cell type boundaries organize plant development. eLife 6, e27421.

Campbell, L., Turner, S., 2017. Regulation of vascular cell division. Journal of Experimental Botany 68, 27-43.

Carlsbecker, A., Lee, J.-Y., Roberts, C.J., et al., 2010. Cell signalling by microRNA165/6 directs gene dosedependent root cell fate. Nature 465, 316-321.

Carluccio, L.M., Hueber, F.M., Banks, H.P., 1966. Archaeopteris macilenta, anatomy and morphlogy of its frond. American Journal of Botany 53, 719-730. 
Cascales-Miñana, B., Steemans, P., Servais, T., et al., 2019. An alternative model for the earliest evolution of vascular plants. Lethaia 52, doi: 10.1111/let.12323.

Cronk, Q.C.B., 2009. The molecular organography of plants. Oxford University Press, Oxford, UK. Cui, H., Levesque, M.P., Vernoux, T., et al., 2007. An evolutionarily conserved mechanism delimiting SHR movement defines a single layer of endodermis in plants. Science 316, 421-425.

de Luis Balaguer, M.A., Fisher, A.P., Clark, N.M., et al., 2017. Predicting gene regulatory networks by combining spatial and temporal gene expression data in Arabidopsis root stem cells. Proceedings of the National Academy of Sciences USA 114, E7632-E7640.

Decombeix, A.-L., Boura, A., Tomescu, A.M.F., 2019. Plant hydraulic architecture through time: lessons and questions on the evolution of vascular systems. IAWA Journal 40, doi: 10.1163/2294193240190254

Delevoryas, T., 1964. Ontogenetic studies of fossil plants. Phytomorphology 14, 299-314.

Dennis, R.L., 1974. Studies of Paleozoic ferns: Zygopteris from the Middle and Late Pennsylvanian of the United States. Palaeontographica B 148, 95-136.

Di Laurentio, L., Wysocka-Diller, J.W., Malamy, J.E., et al., 1996. The SCARECROW gene regulates an asymmetric cell division that is essential for generating the radial organization of the Arabidopsis root. Cell 86, 423-433.

Donner, T.J., Scarpella, E., 2009. Auxin-transport-dependent leaf vein formation. Botany 87, 678-684.

Drapek, C., Sparks, E.E., Marhavy, P., et al., 2018. Minimum requirements for changing and maintaining endodermis cell identity in the Arabidopsis root. Nature Plants 4, 586-595.

Edwards, D., 1970. Further observations on the Lower Devonian plant, Gosslingia breconensis Heard. Philosophical Transactions of the Royal Society of London B 258, 225-243.

Edwards, D., 1981. Studies on Lower Devonian petrifactions from Britain. 2. Sennicaulis, a new form genus for sterile axes based on pyrite and limonite petrifactions from the Senni beds. Review of Palaeobotany and Palynology 32, 207-226.

Edwards, D., 1994. Toward an understanding of pattern and process in the growth of early vascular plants. In: Ingram, D.D., Hudson, A. (Eds.), Shape and Form in Plants and Fungi. London: Academic Press/Linnean Society of London, pp. 39-59.

Edwards, D., Davies, K.L., Axe, L. 1992. A vascular conducting strand in the early land plant Cooksonia. Nature 357, 683-685.

Eggert, D.A., 1961. The ontogeny of Carboniferous arborescent Lycopsida. Palaeontographica B 108, 4392.

Esau, K., 1965. Plant anatomy. Second edition. Wiley, New York.

Esau, K., 1977. Anatomy of seed plants. Second edition. Wiley, New York.

Farmer, J.B., Hill, T.G., 1902. On the arrangement and structure of the vascular strands in Angiopteris evecta, and some other Marattiaceae. Annals of Botany 16, 371-402.

Floyd, S.K., Bowman, J.L., 2004. Ancient microRNA target sequences in plants. Nature 428, 485-486.

Floyd, S.K., Bowman, J.L., 2006. Distinct developmental mechanisms reflect the independent origins of leaves in vascular plants. Current Biology 16, 1911-1917.

Floyd, S.K., Bowman, J.L., 2007. The ancestral developmental tool kit of land plants. International Journal of Plant Sciences 168, 1-35.

Floyd, S.K., Bowman, J.L., 2010. Gene expression patterns in seed plant shoot meristems and leaves: homoplasy or homology? Journal of Plant Research 123, 43-55.

Floyd, S.K., Zalewski, C.S., Bowman, J.L., 2006. Evolution of class III Homeodomain-leucine zipper genes in streptophytes. Genetics 173, 373-388.

Frank, M.H., Edwards, M.B., Schultz, E.R., et al., 2015. Dissecting the molecular signatures of apical celltype shoot meristems from two ancient land plant lineages. New Phytologist 207, 893-904. 
Fukaki, H., Wysocka-Diller, J.W., Kato, T., et al., 1998. Genetic evidence that the endodermis is essential for shoot gravitropism in Arabidopsis thaliana. Plant Journal 14, 425-430.

Gardiner, J., Donner, T.J., Scarpella, E., 2011. Simultaneous activation of SHR and ATHB8 expression defines switch to preprocambial cell state in Arabidopsis leaf development. Developmental Dynamics 240, 261-270.

Gensel, P.G., 1976. Renalia hueberi, a new plant from the Lower Devonian of Gaspé. Review of Palaeobotany and Palynology 22, 19-37.

Gensel, P.G., 1984. A new Lower Devonian plant and the early evolution of leaves. Nature 309, 785-787.

Gola, E.M., Jernstedt, J.A., Zagorska-Marek, B., 2007. Vascular architecture in shoots of early divergent vascular plants, Lycopodium clavatum and Lycopodium annotinum. New Phytologist 174, 774-786.

Good, C.W., Taylor, T.N., 1972. The ontogeny of Carboniferous articulates: the apex of Sphenophyllum. American Journal of Botany 59, 617-626.

Gwynne-Vaughn, D.T., 1901. Observations on the anatomy of solenostelic ferns. I. Loxsoma. Annals of Botany 15, 71-98.

Hébant, C., 1977. The conducting tissues of bryophytes. J. Cramer, Vaduz.

Helariutta, Y., Fukaki, H., Wysocka-Diller, J.W., et al., 2000. The SHORT-ROOT gene conrols radial patterning of the Arabidopsis root through radial signalling. Cell 101, 555-567.

Hetherington, A.J., Dubrovski, J.G., Dolan, L., 2016. Unique cellular organisation in the oldest root meristem. Current Biology 26, 1629-1633.

Hetherington, A.J., Dolan, L., 2018. Rhynie chert fossils demonstrate the independent origin and gradual evolution of lycophyte roots. Current Opinion in Plant Biology 47, 119-126.

Hisanaga, T., Miyashima, S., Nakajima, K., 2014. Small RNAs as positional signal for pattern formation. Current Opinion in Plant Biology 21, 37-42.

Ilegems, M., Douet, V., Meylan-Bettex, M., et al., 2010. Interplay of auxin, KANADI and Class III HD-ZIP transcription factors in vascular tissue formation. Development 137, 975-984.

Jeffrey, E.C., 1899. The morphology of the central cylinder in the angiosperms. Transactions of the Royal Canadian Institute 6, 599-636.

Juarez, M.T., Kui, J.S., Thomas, J., et al., 2004. microRNA-mediated repression of rolled leaf1 specifies maize leaf polarity. Nature $428,84-88$.

Karafit, S.J., Rothwell, G.W., Stockey, R.A., Nishida H., 2006. Evidence for sympodial vascular architecture in a filicalean fern rhizome: Dickwhitea allenbyensis gen. et sp. nov. (Athyriaceae). International Journal of Plant Sciences 167, 721-727.

Kenrick, P., Crane, P.R., 1997. The origin and early diversification of land plants. Smithsonian Institution Press, Washington D.C., USA.

Kidston, R., Gwynne-Vaughan, D.T., 1914. On the fossil Osmundaceae. Part V. Transations of the Royal Society of Edinburgh 50, 469-480.

Kidston, R., Lang, W.H., 1917. On Old Red Sandstone plants showing structure from the Rhynie Chert Bed, Aberdeenshire. Part 1. Rhynia gwynne-vaughani Kidston and Lang. Transactions of the Royal Society of Edinburgh 51, 751-784.

Kidston, R., Lang, W.H., 1920a. On Old Red Sandstone plants showing structure, from the Rhynie Chert Bed, Aberdeenshire. Part II. Additional notes on Rhynia gwynne-vaughani, Kidston and Lang; with descriptions of Rhynia major, n. sp., and Hornea lignieri, n. g., n. sp. Transactions of the Royal Society of Edinburgh 52, 603-627.

Kidston, R., Lang, W.H., 1920b. On Old Red Sandstone plants showing structure, from the Rhynie Chert Bed, Aberdeenshire. Part III. Asteroxylon mackiei, Kidston and Lang. Transactions of the Royal Society of Edinburgh 52, 643-680.

Leclercq, S., Banks, H.P., 1962. Pseudosporochnus nodosus sp. nov., a Middle Devonian plant with cladoxylalean affinities. Palaeontographica B 110, 1-34. 
958

959

960

961

962

963

964

965

966

967

968

969

970

971

972

973

974

975

976

977

978

979

980

981

982

983

984

985

986

987

988

989

990

991

992

993

994

995

996

997

998

999

1000

1001

1002

1003

1004
Levesque, M.P., Vernoux, T., Busch, W., et al., 2006. Whole-genome analysis of the SHORT-ROOT developmental pathway in Arabidopsis. PLoS Biology 4, e 143.

Ma, Y., Steeves, T.A., 1992. Auxin effects on vascular differentiation in ostrich fern. Annals of Botany 70, 277-282.

Ma, Y., Steeves, T.A., 1995. Effects of developing leaves on stelar pattern development in the shoot apex of Matteuccia struthiopteris. Annals of Botany 75, 593-603.

Matsunaga, K.K.S., Tomescu, A.M.F., 2017. An organismal concept for Sengelia radicans gen. et sp. nov. - morphology and natural history of an Early Devonian lycophyte. Annals of Botany 119, 10971113.

Matten, L.C., 1968. Actinoxylon banksii gen. et sp. nov.: a progymnosperm from the Middle Devonian of New York. American Journal of Botany 55, 773-782.

Mattsson, J., Ckurshumova, W., Berleth, T., 2003. Auxin signaling in Arabidopsis leaf vascular development. Plant Physiology 131, 1327-1339.

Melchior, R.C., Hall, J.W., 1961. A calamitean shoot apex from the Pennsylvanian of lowa. American Journal of Botany 48, 811-815.

Miller, C.N.J., 1971. Evolution of the fern family Osmundaceae based on anatomical studies. Contributions from the Museum of Paleontology, University of Michigan 23, 105-169.

Miyashima, S., Koi, S., Hashimoto, T., Nakajima, K., 2011. Non-cell-autonomous microRNA165 acts in a dosedependent manner to regulate multiple differentiation status in the Arabidopsis root.

Development 138, 2303-2313.

Muraro, D., Mellor, N., Pound, M.P., et al., 2014. Integration of hormonal signaling networks and mobile microRNAs is required for vascular patterning in Arabidopsis roots. Proceedings of the National Academy of Sciences USA 111, 857-862.

Namboodiri, K.K., Beck, C.B., 1968. A comparative study of the primary vascular system of conifers. III. Stelar evolution in gymnosperms. American Journal of Botany 55, 464-472.

Ogura, Y., 1972. Comparative anatomy of vegetative organs of the pteridophytes. Gebruder Borntraeger, Berlin.

Prigge, M.J., Clark, S.E., 2006. Evolution of the class III HD-Zip gene family in land plants. Evolution and Development 8, 350-361.

Posthumus, O., 1924. On some principles of stelar morphology. De Bussy, Amsterdam.

Ramachandran, P., Carlsbecker, A., Etchells, J.P., 2017. Class III HD-ZIPs govern vascular cell fate: an HD view on patterning and differentiation. Journal of Experimental Botany 68, 55-69.

Reinhardt, D., 2005. Phyllotaxis - a new chapter in an old story about beauty and magic numbers. Current Opinion in Plant Biology 8, 487-493.

Remy W., Hass H., 1986. Gothanophyton zimmermannii nov. gen. nov. spec., eine Pflanze mit komplexem stellar Körper aus dem Emsium. Argumenta Palaeobotanica 7, 9-69.

Rothwell, G.W., 1976. Primary vasculature and gymnosperm systematics. Review of Palaeobotany and Palynology 22, 193-206.

Rothwell, G.W., 1992. The evolution of vascular architecture. [unpublished; see Appendix]

Rothwell, G.W., Erwin, D.M., 1987. Origin of seed plants: an aneurophyte/seed-fern link elaborated. American Journal of Botany 74, 970-973.

Sanchez, P., Nehlin, L., Greb, T., 2012. From thin to thick: major transitions during stem development. Trends in Plant Science 17, 113-121.

Sanders, H.L., Langdale, J.A., 2013. Conserved transport mechanisms but distinct auxin responses govern shoot patterning in Selaginella kraussiana. New Phytologist 198, 419-428.

Scarpella, E., Rueb, S., Boot, K.J.M., et al., 2000. A role for the rice homeobox gene Oshox1 in provascular cell fate commitment. Development 127, 3655-3669. 
1005

1006

1007

1008

1009

1010

1011

1012

1013

1014

1015

1016

1017

1018

1019

1020

1021

1022

1023

1024

1025

1026

1027

1028

1029

1030

1031

1032

1033

1034

1035

1036

1037

1038

1039

1040

1041

1042

1043

1044

1045

1046

1047

1048

1049

1050

1051

1052
Scheckler, S.E., 1978. Ontogeny of progymnosperms. II. Shoots of Upper Devonian Archaeopteridales. Canadian Journal of Botany 56, 3136-3170.

Schmid, R., 1982. The terminology and classification of steles. Botanical Review 48, 817-931.

Schoute, J.C., 1903. Die Stelär-Theorie. Gustav Fischer, Jena, Germany.

Scott, D.H., 1902. Professor Jeffrey's theory of the stele. New Phytologist 1, 207-212.

Serbet, R., Rothwell, G.W., 1992. Characterizing the most primitive seed ferns. I. A reconstruction of Elkinsia polymorpha. International Journal of Plant Sciences 153, 602-521.

Siebers, A.M., 1971. Initiation of radial polarity in the interfascicular cambium of Ricinus communis L. Acta Botanica Neerlandica 20, 211-220.

Slater, B.J., McLoughlin, S., Hilton, J., 2015. A high-latitude Gondwanan lagerstätte: The Permian permineralised peat biota of the Prince Charles Mountains, Antarctica. Gondwana Research 27, 1446-1473.

Soe, K., 1959. Morphogenetic studies on Onoclea sensibilis L. Ph. D. thesis, Harvard University, Cambridge, USA.

Soria, A., Meyer-Berthaud, B., 2003. Occurrence of whorled organotaxis in the cladoxylopsid Pietzschia polyupsilon Read and Campbell. Review of Palaeobotany and Palynology 124, 29-49.

Stein, W.E., 1993. Modeling the evolution of stelar architecture in vascular plants. International Journal of Plant Sciences 154, 229-263.

Stewart, W.N., Rothwell, G.W., 1993. Paleobotany and the evolution of plants. Second edition. Cambridge University Press, Cambridge, UK.

Strullu-Derrien, C., Kenrick, P., Tafforeau, P., et al., 2014. The earliest fossil wood and its hydraulic properties documented in c. 407-million-year-old fossils using synchrotron microtomography. Botanical Journal of the Linnean Society 175, 423-437.

Tansley, A.G., 1896. The stelar theory; a history and a criticism. Science Progress 5, 133-150, 215-226.

Tansley, A.G., 1907. Lectures on the evolution of the filicinean vascular system. New Phytologist 6, 2535, 53-68, 109-120, 135-147, 148-155, 187-203, 219-238, 253-269.

Tansley, A.G., 1908. Lectures on the evolution of the filicinean vascular system. New Phytologist 7, 1-16, 29-40.

Toledo, S., Bippus, A.C., Tomescu, A.M.F., 2018. Buried deep beyond the veil of extinction: euphyllophyte relationships at the base of the spermatophyte clade. American Journal of Botany 105, 1264-1285.

Tomescu, A.M.F., 2008. The endodermis: a horsetail's tale. New Phytologist 177, 291-295.

Tomescu, A.M.F., 2009. Megaphylls, microphylls and the evolution of leaf development. Trends in Plant Science 14, 5-12.

Tomescu, A.M.F., Escapa, I.H., Rothwell, G.W., et al., 2017. Developmental programmes in the evolution of Equisetum reproductive morphology: a hierarchical modularity hypothesis. Annals of Botany 119, 489-505.

Troop, J.E., Mickel, J.T., 1968. Petiolar shoots in the Dennstaedtioid and related ferns. American Fern Journal 58, 64-70.

Unger, F., 1856. Schiefer- und Sandsteinflora. Denkschriften der Kaiserlichen Akademie der Wissenschaften zu Wien. Mathematisch-Naturwissenschaftliche Classe 11, 139-182.

Van Fleet, D.S., 1950. The cell forms, and their common substance reactions, in the parenchymavascular boundary. Bulletin of the Torrey Botanical Club 77, 340-353.

Van Fleet, D.S., 1961. Histochemistry and function of the endodermis. Botanical Review 27, 165-220. van Tieghem, P., Douliot, H., 1886a. Sur les tiges à plusieurs cylindres centraux. Bulletin de la Société Botanique de France 33, 213-216.

van Tieghem, P., Douliot, H., 1886b. Sur la polystélie. Annales des Sciences Naturelles, Botanique, Série $7,3,275-322$. 
1053 Vasco, A., Smalls, T.L., Graham, S.W., et al., 2016. Challenging the paradigms of leaf evolution: class III 1054 HD-Zips in ferns and lycophytes. New Phytologist 212, 745-758.

1055

1056

1057

1058

1059

1060

1061

1062

1063

1064

1065

1066

1067

1068

Wang, H., Avci, U., Nakashima, J., et al., 2010. Mutation of WRKY transcription factors initiates pith secondary wall formation and increases stem biomass in dicotyledonous plants. Proceedings of the National Academy of Sciences USA 107, 22338-22343.

Wardlaw, C.W., 1946. Experimental and analytical studies of pteridophytes. VII. Stelar morphology: the effect of defoliation on the stele of Osmunda and Todea. Annals of Botany 9, 97-107.

White, R.A., Weidlich, W.H., 1995. Organization of the vascular system in the stems of Diplazium and Blechnum (Filicales). American Journal of Botany 82, 982-991.

Wight, D.C., 1987. Non-adaptive change in early land plant evolution. Paleobiology 13, 208-214.

Williams, S., 1927. A critical examination of the Vittarieae with a view to their systematic comparison. Transactions of the Royal Society of Edinburgh 55, 173-217.

Wysocka-Diller, J.W., Helariutta, Y., Fukaki, H., et al., 2000. Molecular analysis of SCARECROW function reveals a radial patterning mechanism common to root and shoot. Development 127, 595-603.

Xu, H.-H., Berry, C.M., Stein, W.E., et al., 2017. Unique growth strategy in the Earth's first trees revealed in silicified fossil trunks from China. Proceedings of the National Academy of Sciences USA 114,

1069 12009-12014. 
Figures

1071

(a)
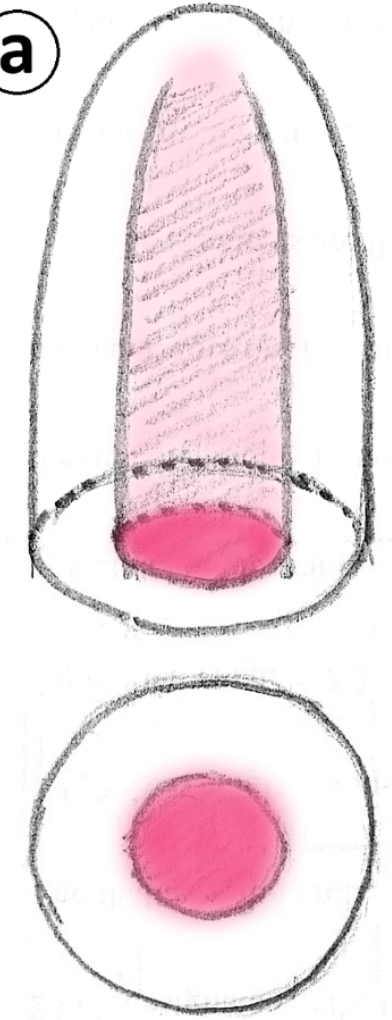
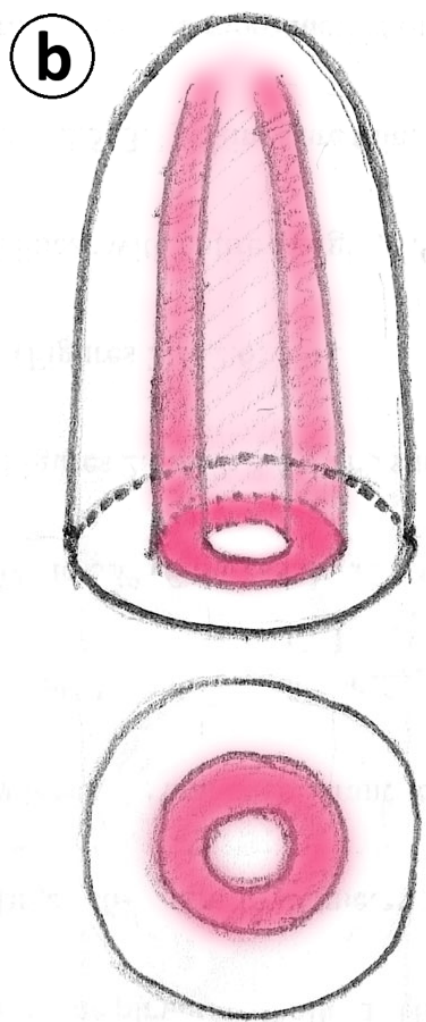
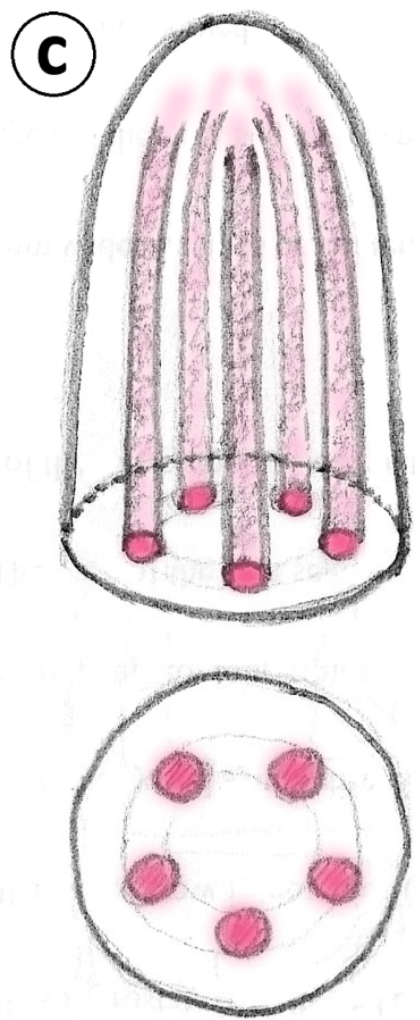

1072

1074

1075

1076

1077

1078

1079

1080

1081

1082

1083

Figure 1. The geometry of the procambium (pink/red) in the apical meristem region (top panel) provides a criterion for defining three main types of stele (seen in cross section in the bottom panel). A protostele (a) is a stele derived from a solid central strand of procambium. The procambium is surrounded by ground meristem that matures into the cortex. A siphonostele (b) develops from a hollow cylinder of procambium. Aside from ground meristem that differentiates into the cortex that surrounds the stele, siphonostelic axes possess a central cylinder of ground meristem that forms the mature pith. A eustele (c) is a stele derived from a number of discrete procambial strands that, taken together, describe a more-or-less circular outline in cross sections, separating an outer cortex and a central pith, both derived from ground meristem. The parenchymatous areas between adjacent vascular strands are interfascicular areas (also termed pith rays). 
1084

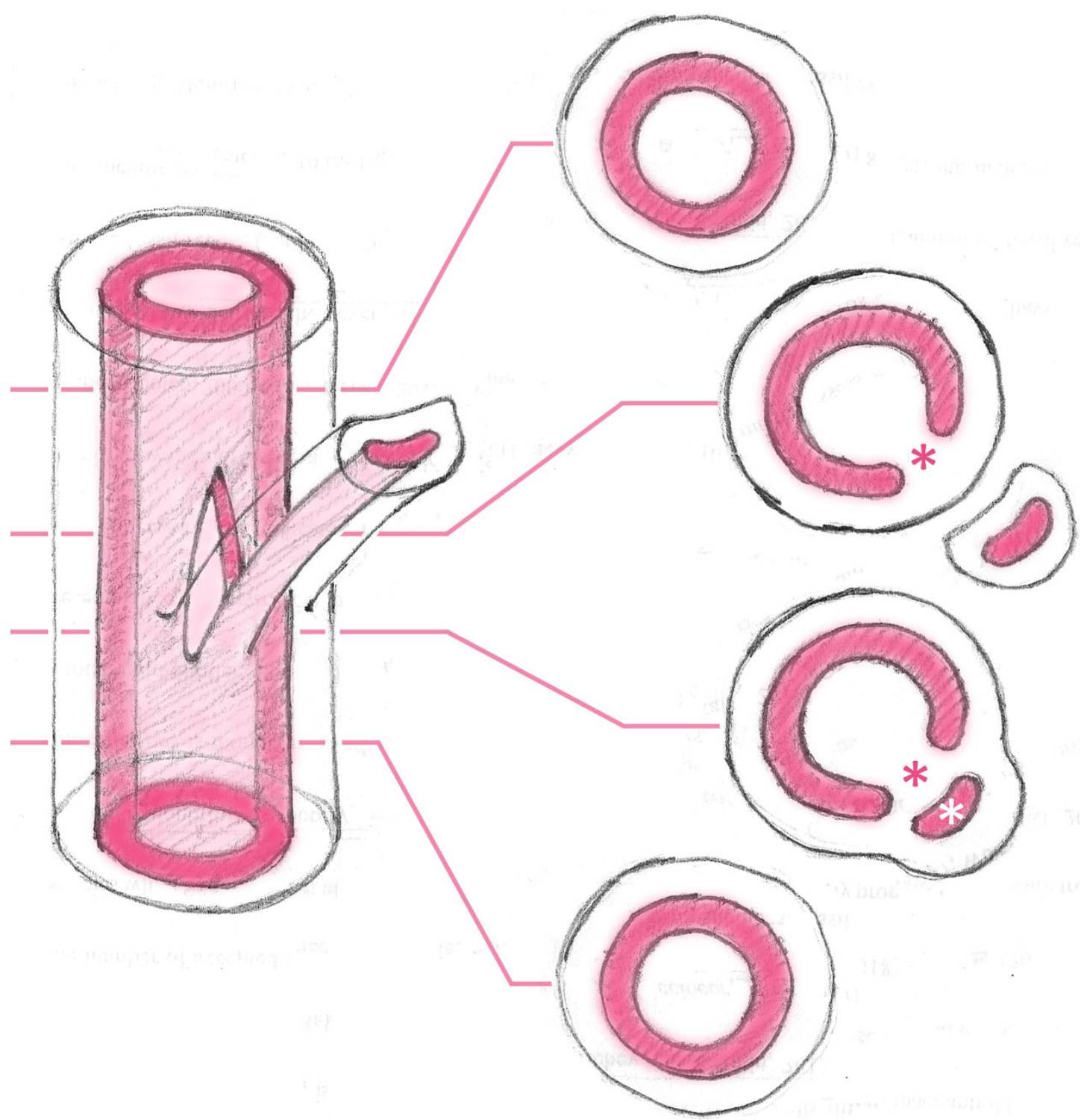

Figure 2. The leaf gap (pink asterisk) produced in a siphonostele by the divergence of a vascular trace supplying the base of a leaf (leaf trace; white asterisk); tissues of the stele and leaf trace shown in 1089 pink/red. 
(a)

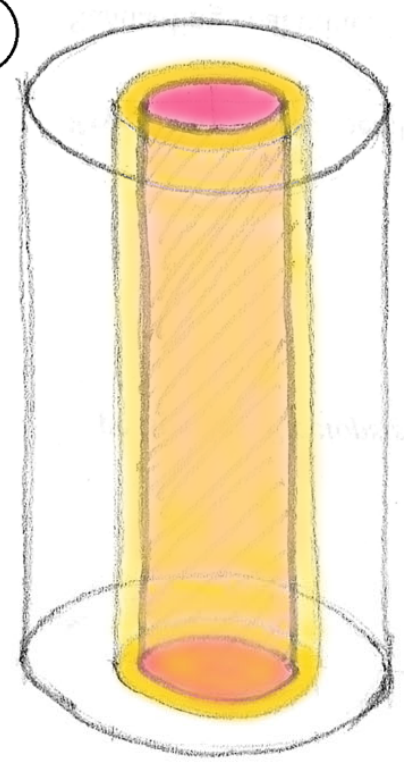

1091

1092

1093

1094

1095

1096

1097

1098 white tissues of the cortex. (b)

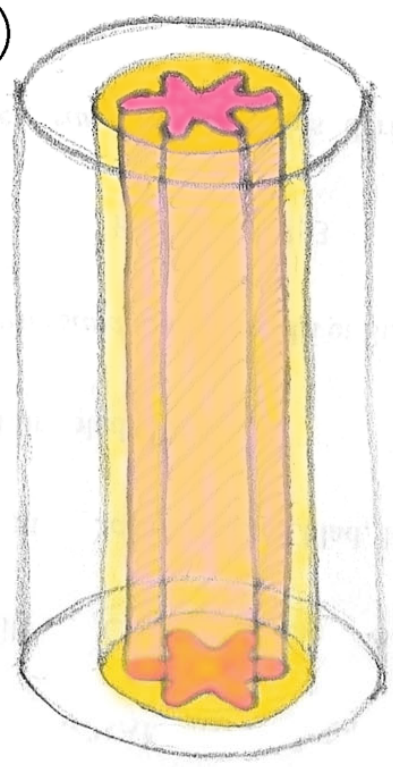

(C)

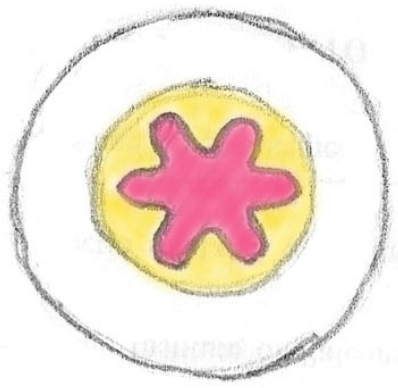

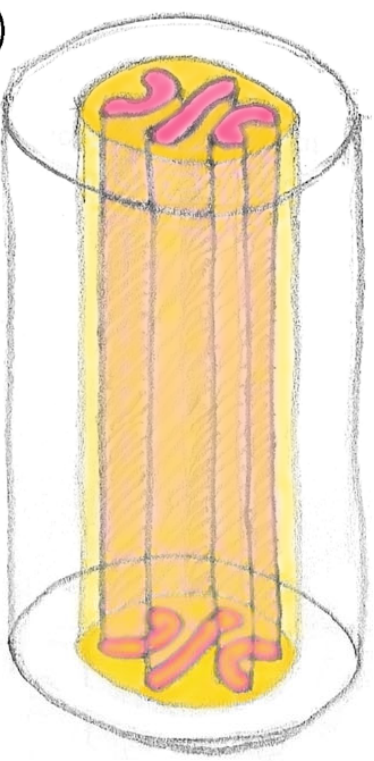

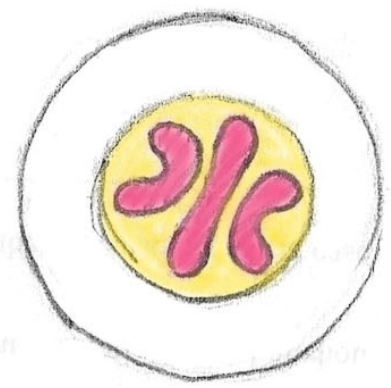

Figure 3. Protosteles (top panel) are divided, based on the cross-sectional geometry of the primary xylem (bottom panel) into haplosteles, wherein the xylem has circular to oval shape in cross section (a), actinosteles, wherein the xylem has has a lobed (ribbed) shape (b), and plectosteles, with the xylem irregularly dissected into lobes and bands (c); xylem shown in red and additional stele tissues in yellow; the endodermis, not depicted, follows the boundary between the yellow tissues of the stele and the 
a)

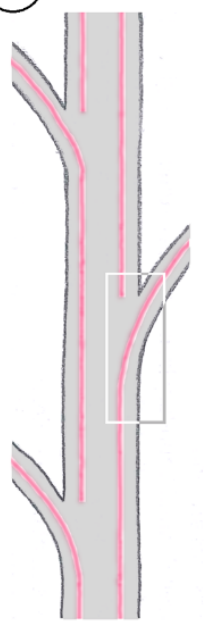

(b)

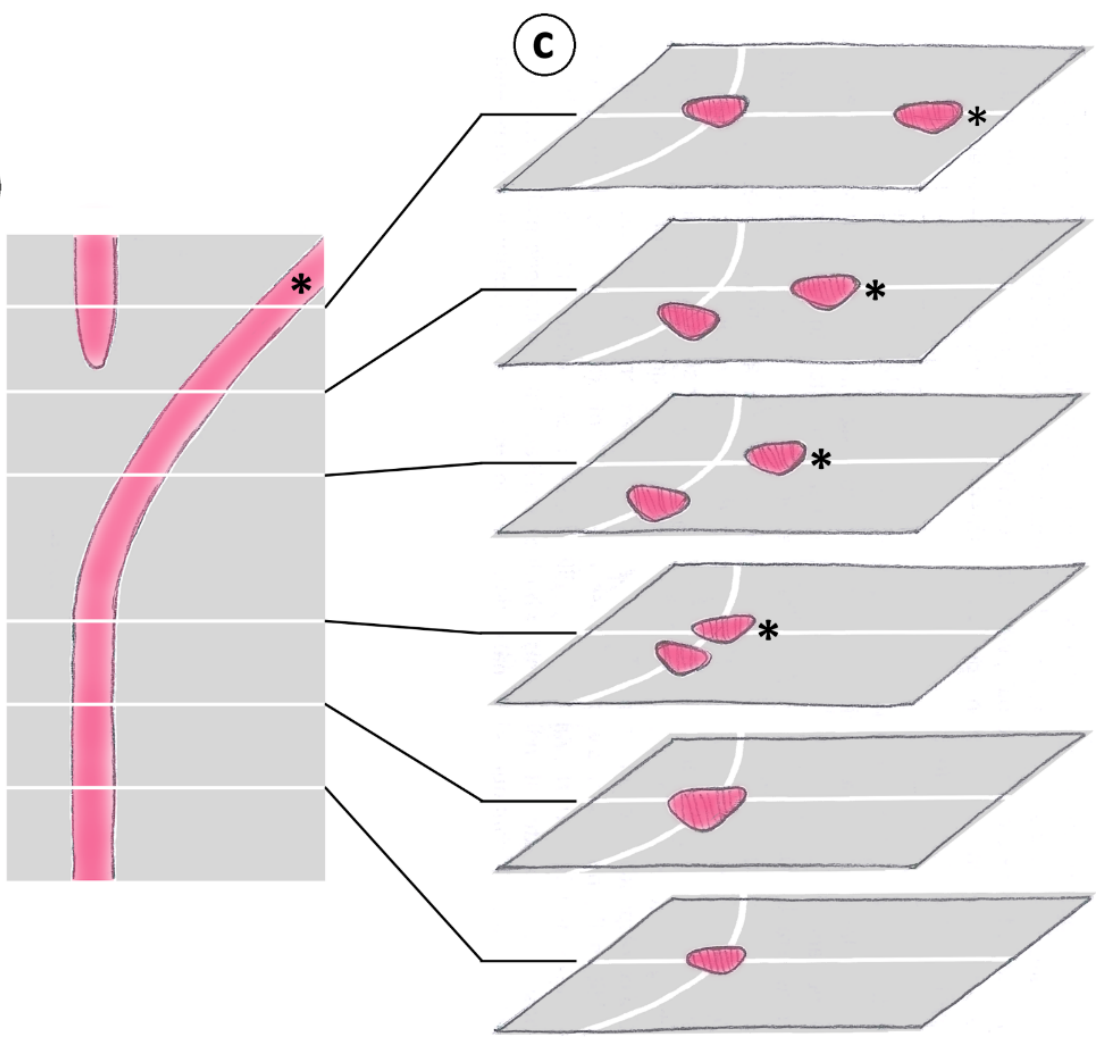

Figure 4. Longitudinal sections through eustelic axes often show vascular tissue configurations that look misleadingly like leaf gaps $(\mathbf{a}, \mathbf{b})$. In the vicinity of the shoot apical meristem this configuration is due to the fact that nodal tissues mature earlier than those of the internodes, thus, a procambial strand that is conspicuous in a node can appear to lose its substance along its trajectory through the internode below, and to reappear in the next node underneath. In the mature shoot portions of most seed plants, leaf traces (asterisk) diverge from cauline bundles in a tangential direction (c, bottom three planes of section) before traversing the cortex in a radial direction and upwards (c, top three planes of section). This leads to tangential displacement of the cauline bundle above the divergence (c), as a result of which the bundle shows a hiatus immediately above the node in longitudinal sections (b), similar to that produced by a leaf gap in a siphonostele longitudinal section. 
1112

1113

1114

1115

1116

1117

1118

1119

1120

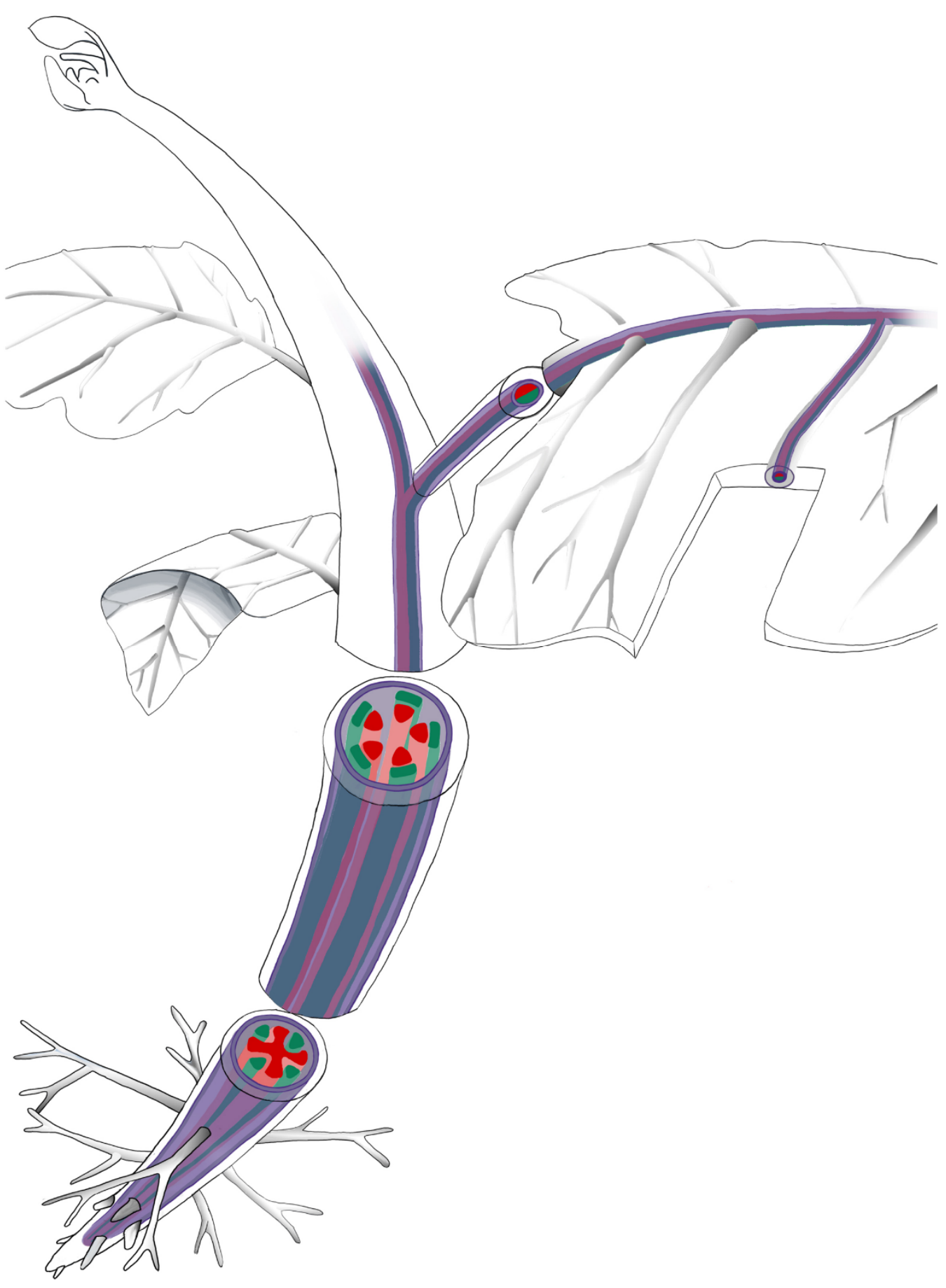

Figure 5. The layers that mark boundaries between the vascular tissues (primary xylem in red and primary phloem in green) and ground tissues. These layers - the endodermis in roots, the starch sheath in stems, and the bundle sheaths of leaf veins (all shown in purple) - are continuous throughout the plant body, despite having distinct physiological functions, and the available evidence suggests that they are specified by the same regulatory modules throughout the plant body. Artwork by Danza ChisholmSims. 
1121

1122

1123

1124

1125

1126

1127

1128

1129

1130

1131

1132

1133

1134

1135

1136

1137

1138

1139

1140

1141

1142

1143

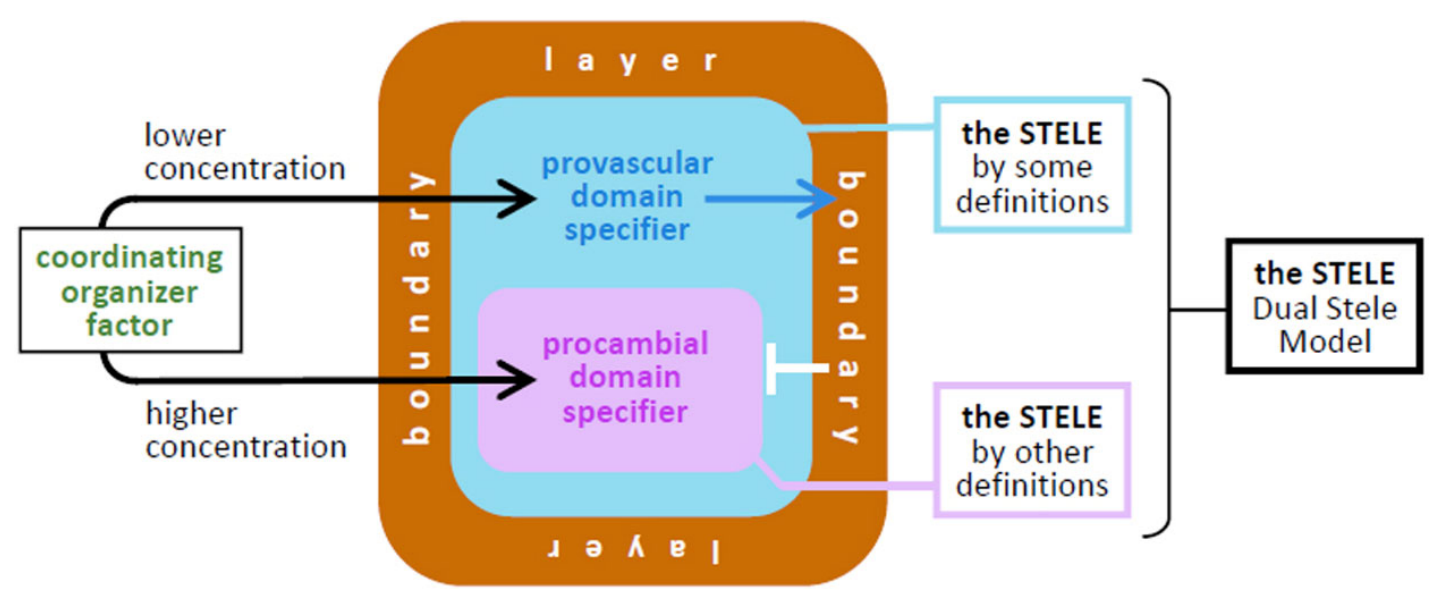

Figure 6. The stele has been defined traditionally as comprising either the tissues derived from procambium or the tissues contained within a boundary layer. The dual stele model provides a unifying explanation for the nature and evolution of the stele, consistent with both the procambial and the boundary layer views. This model posits two cell fate specification mechanisms that are deployed sequentially and delimit increasingly more narrowly circumscribed and more specialized developmental domains. The first mechanism (i) specifies a provascular domain (blue), wherein cells maintain competency to differentiate into procambial tissue, and (ii) establishes (blue arrow) a boundary layer (brown) that separates this domain from the neighboring accessory domain. The second mechanism specifies procambial identity (pink) in cells within the provascular domain that will differentiate into xylem and phloem. The two cell fate specification mechanisms that determine the provascular and procambial domains are connected through the intermediary of the boundary layer, which inhibits the activity of the procambial domain specifier (white inhibitory interaction symbol), thus constraining the physical extent of this domain. The two mechanisms are also coordinated by an organizer factor that acts in a dosage-dependent manner: promoting the provascular domain specifier at lower concentrations and the procambial domain specifier at higher concentrations. Current understanding of developmental regulation in stele tissues and boundary layers suggests that auxin may be the coordinating organizer factor, with SHR (homologs) and class III HD-Zip genes (C3HDZ) the provascular and procambial domain specifiers, respectively. SHR is known to act in specification of the boundary layer and in activation, within this layer, of miR165/166, which diffuse back into the provascular domain, inhibiting the activity of $\mathrm{C} 3 \mathrm{HDZ}$ and constraining the extent of the procambial domain. 


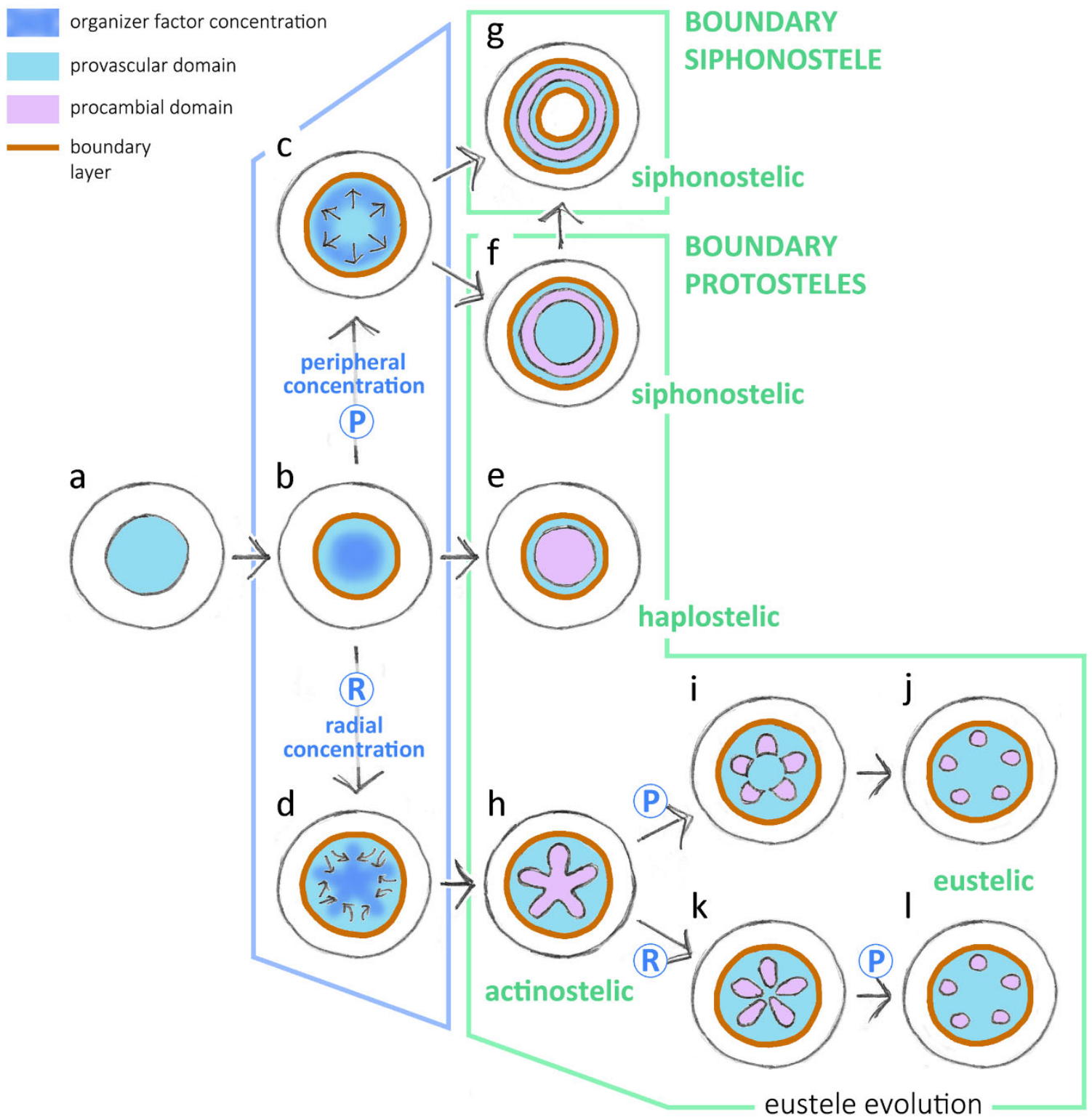

Figure 7. Stele types in an evolutionary-developmental perspective informed by the dual stele model. A central column of tissue with provascular identity (light blue) and the boundary layer (brown) that it establishes at its periphery $(\mathbf{a} \rightarrow \mathbf{b})$ define a central domain, corresponding to the stele, and an outer (accessory) domain. This type of general organization is termed a boundary protostele in the classification proposed here. Within the provascular domain, a central zone of higher concentration (dark blue) of the organizer factor (auxin) specifies a strand of procambial domain (pink) with terete geometry $(\mathbf{b} \rightarrow \mathbf{e})$, as seen in protosteles of the haplostele type (e; haplostelic boundary protostele). Peripheral redistribution $(P)$ of organizer factor concentrations $(\mathbf{b} \rightarrow \mathbf{c})$ specifies a procambial domain in the shape of a hollow cylinder typical of siphonostelic organization (f; siphonostelic boundary protostele). A marked depletion in organizer factor at the center of the stele leads to specification of a second boundary layer and to a provascular domain shaped like a hollow cylinder; in the classification proposed here, this organization is termed a boundary siphonostele $(\mathbf{g})$. Evolutionary transitions between the two types of siphonostelic organization ( $f \rightarrow g$ ) may be at the origin of the boundary 
1160 siphonosteles known in some plant groups. Radial redistribution $(R)$ of organizer factor concentrations 1161 ( $b \rightarrow \mathbf{d})$ specifies a central procambial domain with vertical ridges and grooves $(\mathbf{d} \rightarrow \mathbf{h})$, as seen in 1162 protosteles of the actinostele type (h; actinostelic boundary protostele). From such actinostelic 1163 configurations, steles with eustelic organization, i.e., procambial domain forming discrete strands (j, l; 1164 eustelic boundary protostele) could have evolved along two pathways: one emphasizing subsequent 1165 peripheral concentration $(P)$ and referred to as medullation $(\mathbf{h} \rightarrow \mathbf{i} \rightarrow \mathbf{j})$; and the other emphasizing 1166 further radial concetration $(R)$ followed by peripheral concentration $(P)$ and referred to as dissection or fragmentation ( $\mathbf{h} \rightarrow \mathbf{k} \rightarrow \mathrm{I}$ ). Stele color coding: boundary layer - brown line; provascular domain - light blue; procambial domain - pink; concentration of organizing factor (auxin) within the provascular domain - dark blue. Blue box - Patterns of organizing factor concentration; green boxes - classification of steles proposed here. Traditional stele types: haplostele (protostele) - e; actinostele (protostele) - $\mathbf{h}$; medullated protostele and ectophloic siphonostele $-\mathbf{f}$; amphiphloic siphonostele $-\mathbf{g}$; eustele $\mathbf{- j}$, I. 
1173

1174

1175

1176

1177

1178

1179

1180

1181

1182

1183

1184

1185

1186

1187

1188

1189

1190
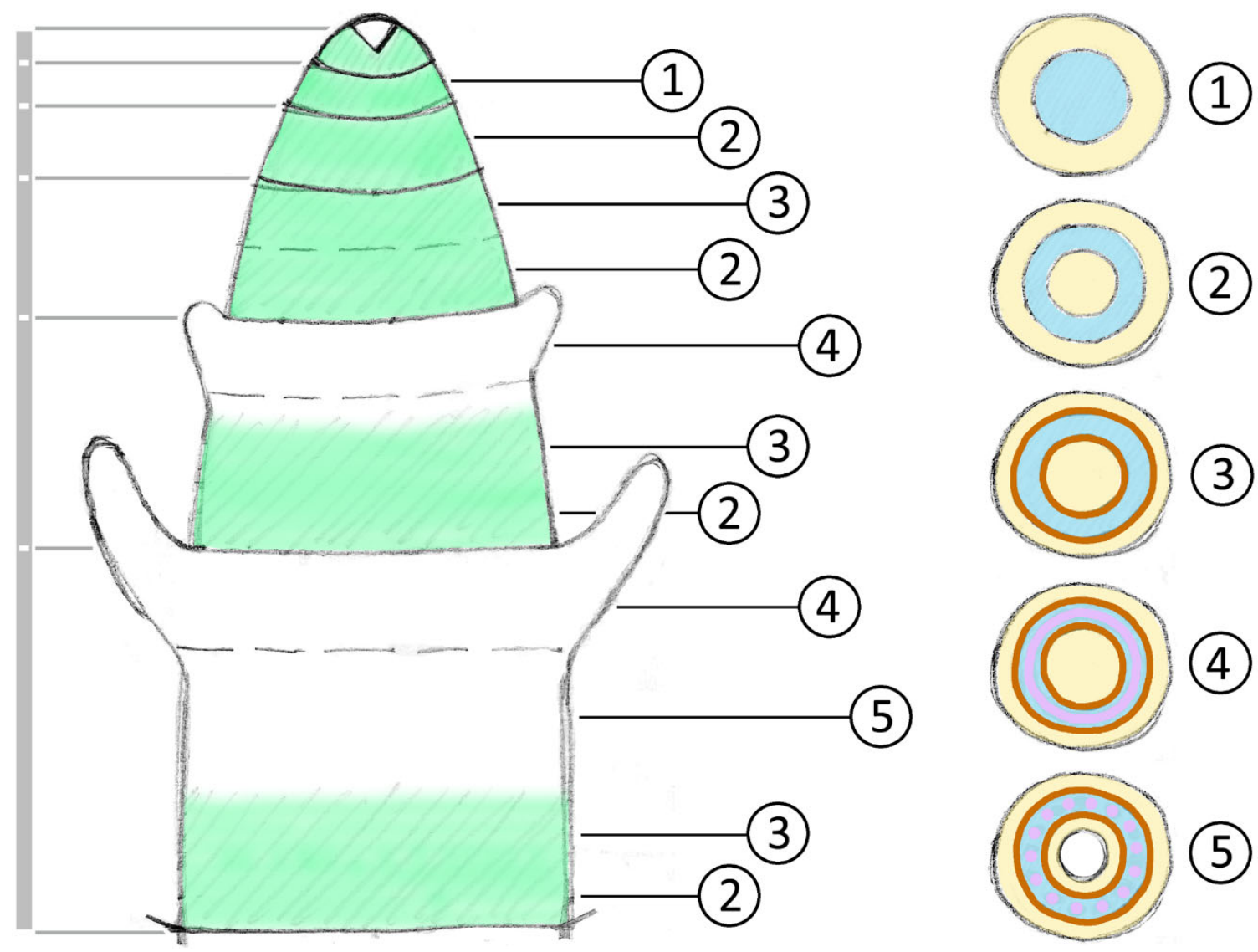

Figure 8. Development of the stele with double endodermis in an Equisetum shoot. Growth arises from the activity of (i) an apical meristem (represented by the apical cell of the shoot at left) that lays down a stack of phytomers (the first six are marked by the gray bars at far left), and (ii) intercalary meristems that are located basally in each phytomer wherein fuel internode elongation. A hypothetical developmental sequence involves several stages (labeled 1 through 5 and mapped on the shoot at left): initial specification of a central provascular domain within young phytomers (1) in early stages of radial patterning; subsequent peripheral concentration leading to a hollow cylinder of provascular domain (2); specification of inner and outer endodermal layers (3) in the upper nodal tier of a phytomer, as this tier starts differentiating from the lower internode tier (dashed line); procambial domain specification (4) in the nodal tier, between the two endodermal layers, while the internode tier remains meristematic (green in the shoot at left), forming an intercalary meristem; in growing internodes (e.g., basal-most phytomer in the shoot at left), acroscopic production of new tissue by the intercalary meristem at high rates and fast internode elongation maintain low levels of auxin in the provascular domain, precluding specification of procambial domain between the two endodermal layers (3); procambial strands differentiate within the provascular domain of the internode (5) along vertical lines corresponding to, and under the influence of, leaf primordia. 


\title{
Appendix
}

Gar W. Rothwell's "The evolution of vascular architecture"

Extended abstract of paper presented in the Katherine Esau International Symposium "Plant structure: concepts, connections, and challenges", March 28-31, 1992, University of California, Davis, USA

\section{The Evolution of Vascular Architecture}

\author{
Gar W. Rothwell
}

Department of Botany, Ohio University, Athens, OH, 45701

\begin{abstract}
Vascular tissues are the focus of considerable attention across a broad spectrum of botanical inquiry. Undoubtedly, this reflects the functional, developmental and phylogenetic significance of this most intricate of all plant tissue systems. While there is a relative consistency to the polyarch, exarch actinosteles found in most true roots, there is a broad spectrum of systematically and functionally correlated variation in the vascular architecture of shoot systems.
\end{abstract}

Traditional studies have, during different periods of time, emphasized divergent facets of vascular architecture. Some of the earliest studies characterized the courses of individual bundles as they traversed stems and diverged to leaves. With the formulation of the stelar theory, emphasis shifted to the overall pattem of vascular tissues in the stem. This approach has demonstrated systematic correlations among shoot systems, and has dramatically impacted our view of land plant evolution. However, a reliance on two-dimensional stelar configurations, and an inconsistency in the inclusion (or exclusion) of secondary tissues somewhat diminished the phylogenetic utility of such work.

More recently, a revival of studies that stress three dimensional architecture of primary tissue systems has set the stage for dramatically increasing the depth with which we understand the vascular tissues of land plants. These studies also allow us to more accurately recognize broad patterns of systematically correlated vascular architectures that may be used to further refine hypotheses of land plant phylogeny. From plant paleontology, we are becoming increasingly aware that conducting tissues have evolved independently in two or more groups of primitive land plants. Nevertheless, the tiny centrarch haplosteles of rhyniophytes provide an archetype for considering broad patterns of stelar changes through time. Such changes have occurred in fundamentally different ways in divergent phylogenetic lineages.

Lycophytes are the most ancient group of land plants with living representatives, and they may be regarded as having vascular architectures that evolved independently of other tracheophytes. Lycophytes display a wide array of exarch protosteles in the stems, and a complex vascular system that characterizes the shoot-derived rooting system of Isoetes and of the extinct rhizomorphic lycophytes. Immediately distal to the rhizomorph in Paurodendron, protoxylem of the centrarch haplostele divides. Three resulting protoxylem strands extend to the periphery of the xylem in conjunction with divergence of the basal leaf traces. This illustrates the ontogenetic transition from a centrarch stele to the exarch stele, and provides a model for the evolutionary origin of exarch lycophyte steles. It also correlates well with known aspects of apical development under the influence of the terminal meristem in Lycopodium.

The evolution of vascular architecture in stems of ferns is well represented by transformational series from solid protosteles to highly dissected dictyosteles. Series occur as chronoclines among Paleozoic representatives of both the Psalixochlaenaceae and Osmundaceae, and also as ontogenetic changes along the length of the stem in extant species. Such stems provide the most convincing evidence for the Jeffreyan concept of siphonosteles with true leaf gaps.

Despite continuing assumptions that eusteles represent highly dissected siphonosteles, the exciting and profound realization that seed plants are both structurally and phylogenetically distinct from ferns has been steadily gaining acceptance. Paleobotanical studies by Beck and others provide convincing evidence that evolution of the seed-plant eustele was associated with longitudinal dissection of a ribbed protostele. These studies demonstrate that the eustele is basically a ring of sympodia lacking true leaf gaps like those of many ferns. They also imply that progymnosperms, rather than ferns, are probably ancestral to seed plants.

Recent phylogenetic analyses have stressed the transition from a protostele to a eustele as an important facet of seed plant evolution. Paleobotanical studies have revealed this to be a gradational change in the degree of longitudinal dissection of metaxylem, for the purpose of character coding the change has been collapsed to a binary transformation in most phylogenetic analyses. In contrast, a survey of the broad range of variation in stelar architecture found among Devonian and Carboniferous lignophytes (progymnosperms + seed plants) suggests that evolution of the eustele was far more complex than previously realized. At the 
present time five parameters of variation have been recognized among the stem steles of primitive seed ferns, and each may reflect a different aspect of stelar evolution. These parameters are (1) variation in the degree of longitudinal dissection of metaxylem, (2) variation in the ratio of tracheids to parenchyma in primary xylem, (3) variation in protoxylem architecture from a central monopodium to a ring of sympodia, (4) variation in the shape of the stele from distinctly ribbed to polygonal, and (5) variation in stelar diameter. Numbers 1, 2, and 3 probably are of the greatest evolutionary significance.

Although most of these parameters show gradational variations, the change in protoxylem architecture appears to be qualitative in nature. Some protostelic seed ferns display a central protoxylem monopodium from which the leaf trace protoxylem diverges. Other protostelic forms have a ring of protoxylem sympodia, one near the base of each stelar rib, and each of these divides to produce leaf trace protoxylem. Possible evidence for a transition from one architecture to the other occurs in sympodial species where there is an intermittent central protoxylem, and in stems that lack both a central protoxylem and a ring of cauline protoxylem sympodia.

This range of protoxylem architecture is best explained by the hypothesis that protosylem differentiation is under the influence of several factors (hormones, sugars, etc.) produced at or translocated to centers in either or both of the terminal meristem and leaf primordia. The hypothesis requires that provascular and protosylem differentiation occur only above a threshold concentration for these influencing factors. Primitive plants without stem/leaf differentiation of the shoot system would have production centers only in the terminal meristem, and thus would have been centrarch. The evolution of leaves from modified branching systems presumably would have led to the progressive transition of auxin production from the terminal meristem to the leaf primordia. Primitive seed plants with a central protoxylem monopodium and marginally mesarch leaf traces are consistent with what could be expected of an early stage in this transition. Forms with discontinuous cauline protoxylem are concordant with what would be expected in stems where the transition was incomplete. And, stems with a ring of protoxylem sympodia, including extant species, are what would be expected where the production of auxin occurs primarily in the leaf primordia.

Observational and experimental data on apical development in Psilotum, Lycopodium, ferns and seed plants are concordant with this hypothesis, and suggest that lycophytes, ferns and seed plants have alternative control mechanisms of vascular pattern formation that may reflect the independent origin of stem/leaf shoot systems in each. They also provide a basis for hypothesizing the mechanism that operated in the apices of rhyniophytes and trimerophytes. These data and hypothesis are summarized in the table that follows. 


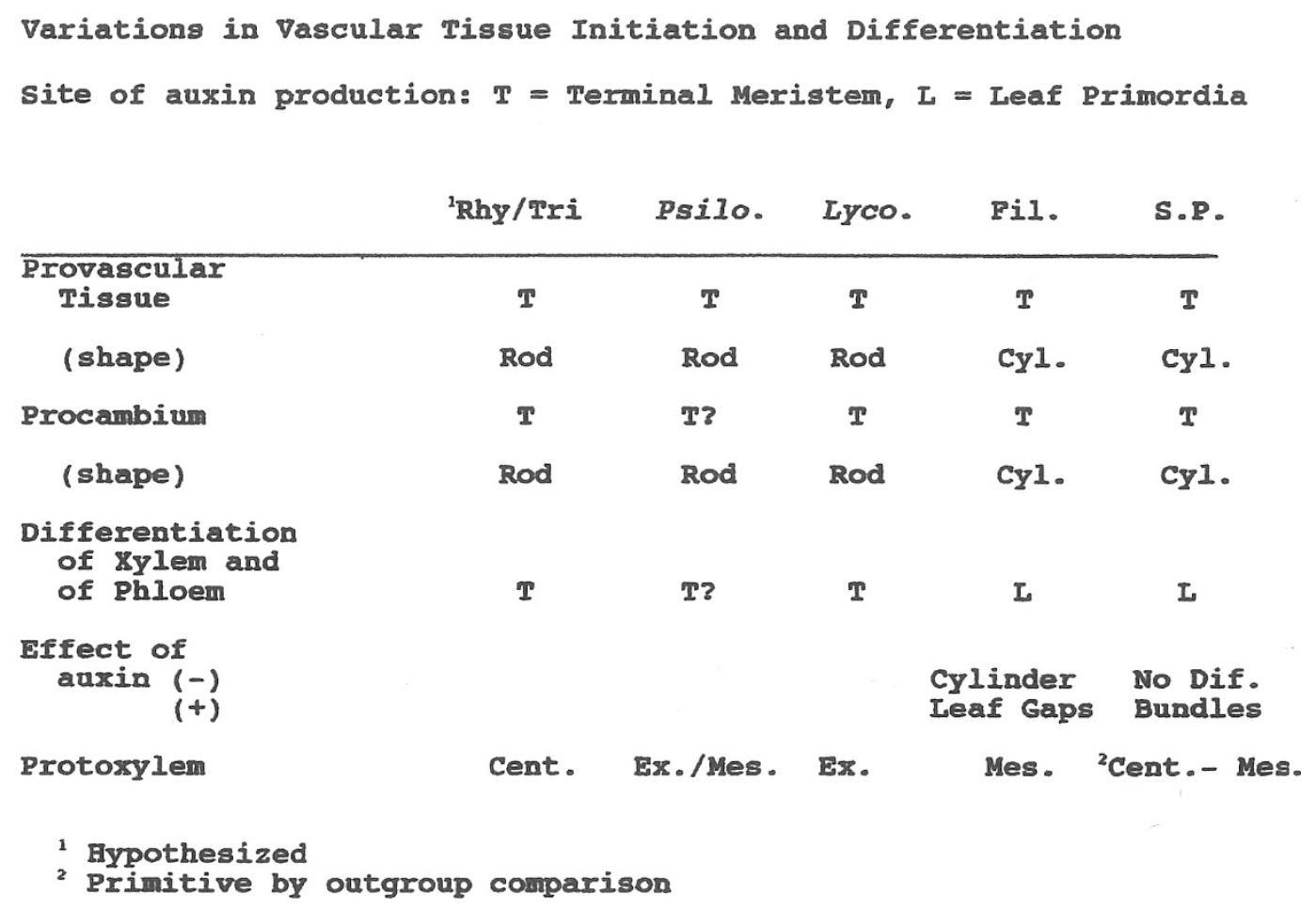




\title{
The Katherine Esau International Symposium
}

\section{Plant Structure: \\ Concepts, Connections \& Challenges}

March 28-31, 1992

\author{
Sponsored by \\ The Division of Biological Sciences \\ The University of California, Davis
}

Contributions in support of the Symposium from:

Calgene, Inc.

Blackwell Scientific Publishers, Ltd. Sandoz Agro, Inc, Entotech, Inc.
Symposium Organizing Committee:

E.M. Gifford, University of Californin, Davis D.G. Gilchrist, University of California, Davis P.B. Green, Stanford University D.R. Kaplan, University of California, Berkeley J.A. Jernstedt, University of California, Davis W.J. Lucas, University of California, Davis V.S. Polito (chnir), University of California, Davis 